\title{
In Silico Model Estimates the Clinical Trial Outcome of Cancer Vaccines
}

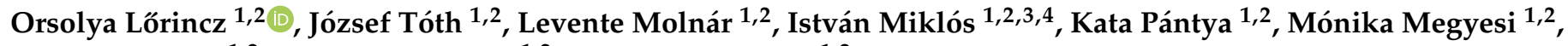 \\ Eszter Somogyi ${ }^{1,2}$, Zsolt Csiszovszki ${ }^{1,2}$ and Enikó R. Tókke ${ }^{1,2, *}$ \\ 1 Treos Bio Ltd., London W1W6XB, UK; orsolya.lorincz@treosbio.com (O.L.); jozsef.toth@treosbio.com (J.T.); \\ levente.molnar@treosbio.com (L.M.); miklos.istvan.74@gmail.com (I.M.); kata.pantya@treosbio.com (K.P.); \\ lakatosmonika@yahoo.com (M.M.); eszter.somogyi@treosbio.com (E.S.); zsolt.csiszovszki@treosbio.com (Z.C.) \\ 2 Treos Bio Zrt, 8200 Veszprém, Hungary \\ 3 Alfréd Rényi Institute of Mathematics, Eötvös Loránd Research Network, 1053 Budapest, Hungary \\ 4 Computer Science and Automation Research Institute (SZTAKI), Eötvös Loránd Research Network, \\ 1111 Budapest, Hungary \\ * Correspondence: Eniko.toke@treosbio.com
}

check for updates

Citation: Lőrincz, O.; Tóth, J.; Molnár, L.; Miklós, I.; Pántya, K.; Megyesi, M.; Somogyi, E.;

Csiszovszki, Z.; Tőke, E.R. In Silico Model Estimates the Clinical Trial Outcome of Cancer Vaccines. Cells 2021, 10, 3048. https://doi.org/ 10.3390/cells10113048

Academic Editors: Paul V. Lehmann and Greg A. Kirchenbaum

Received: 29 September 2021

Accepted: 3 November 2021

Published: 5 November 2021

Publisher's Note: MDPI stays neutral with regard to jurisdictional claims in published maps and institutional affiliations.

Copyright: (c) 2021 by the authors. Licensee MDPI, Basel, Switzerland. This article is an open access article distributed under the terms and conditions of the Creative Commons Attribution (CC BY) license (https:// creativecommons.org/licenses/by/ $4.0 /)$.

\begin{abstract}
Over 30 years after the first cancer vaccine clinical trial (CT), scientists still search the missing link between immunogenicity and clinical responses. A predictor able to estimate the outcome of cancer vaccine CTs would greatly benefit vaccine development. Published results of 94 CTs with 64 therapeutic vaccines were collected. We found that preselection of CT subjects based on a single matching HLA allele does not increase immune response rates (IRR) compared with non-preselected CTs (median 60\% vs. 57\%, $p=0.4490$ ). A representative in silico model population (MP) comprising HLA-genotyped subjects was used to retrospectively calculate in silico IRRs of CTs based on the percentage of MP-subjects having epitope(s) predicted to bind $\geq 1-4$ autologous HLA allele(s). We found that in vitro measured IRRs correlated with the frequency of predicted multiple autologous allele-binding epitopes (AUC 0.63-0.79). Subgroup analysis of multi-antigen targeting vaccine CTs revealed correlation between clinical response rates (CRRs) and predicted multi-epitope IRRs when HLA threshold was $\geq 3(r=0.7463, p=0.0004)$ but not for single HLA allele-binding epitopes ( $r=0.2865, p=0.2491)$. Our results suggest that CRR depends on the induction of broad T-cell responses and both IRR and CRR can be predicted when epitopes binding to multiple autologous HLAs are considered.
\end{abstract}

Keywords: cancer vaccine; HLA genotype; in silico trial; immune response rate; clinical response rate

\section{Introduction}

Based on the proposed mechanism of action of cancer vaccines, one could expect the T-cell mediated killing of malignant cells and thus shrinkage of the tumor. However, to date no clinical trials (CTs) have convincingly shown association between immune response rate (IRR) and clinical response rate (CRR) in terms of tumor shrinkage [1,2], rather survival benefit was found to correlate in some cases [3-6]. These results suggest that eliciting broad and robust immune responses in high proportion of subjects should still be the focus of cancer vaccine development.

The active substances of cancer vaccines are immunogenic epitopes of tumor-associated or tumor-specific proteins. An epitope is a short, 8-25 amino acid long peptide fragment derived from a protein, specifically bound to a human leukocyte antigen (HLA) molecule and consequently can induce immune responses against the diseased cells that express the same peptide. The direct involvement of HLA molecules (major histocompatibility complex, MHC) in T-cell recognition of antigens was first shown in 1974 by Zinkernagel and Doherty [7,8], who received the Nobel Prize for their pioneer work in 1996. In 1987 Wiley and co-workers provided the explanation, which brought forth a paradigm shift, 
not only in the HLA field but also in immunology in general $[9,10]$. Since then, an era of therapeutic vaccines started and today many researchers focus on designing vaccines based on HLA allele-binding predictions. HLAs are encoded by the most polymorphic genes of the human genome. Each person has a maternal and a paternal allele for the three HLA class I molecules (HLA-A* ${ }^{*}$ HLA-B ${ }^{*}$, HLA-C ${ }^{*}$ ). Practically, each person expresses a different combination of six HLA class I molecules that present different epitopes from the same antigen (protein). The current challenge is the accurate prediction of epitopes that induce $\mathrm{CD}^{+}$cytotoxic T-cell (CTL) responses, using computational approaches. Peptides with a predicted HLA-binding affinity in the strong range (half-maximal inhibitory concentration (IC50) $<150 \mathrm{nmol} / \mathrm{L}$ ) are considered more likely to induce CD8 ${ }^{+} \mathrm{T}$-cell responses [11]. The recognition of HLA-presented epitopes by T-cell receptors (TCR) is also a determining part of efficient immune response generation. The heterogeneity of TCRs in a subject has major impact on the immune response; for instance, a single HLA class I influenza epitope was found to produce a few hundreds of different TCRs in each subject while a single HLA class II cancer epitope generated 8-16 different TCR clonotypes with different relative abundance in four cancer patients [12,13]. Another comprehensive study also demonstrated that TCRs specific to the same epitope can be more diverse than TCRs recognizing different epitopes [14]. The models for predicting recognition between TCRs and epitopes are continuously evolving and their reliability is varying [15]. The performance of computational epitope-HLA binding prediction tools is well characterized and high specificity and accuracy is reported for algorithms that are based on either position-specific scoring matrix, neural network, or consensus methods [16]. Therefore, the lack of correlation between HLA-binding predictions and immune responses may not be attributed to the insufficiency of predictors, rather to a missing link between the epitope-HLA binding and the activation of the epitope-specific T-cell within the mechanism of eliciting immune response. This is supported by the finding of a study that less than $1 \%$ of predicted strong-binder epitopes were recognized by T-cells [17]. Many therapeutic cancer vaccines are designed by selecting epitopes derived from tumor-specific proteins that bind to a specific HLA allele (e.g., $\mathrm{A}^{*} 02: 01$ ), or an allele group (e.g., $\left.\mathrm{A} 02\right)$ in order to be immunogenic in a broad population. This became a common practice since $\sim 90 \%$ of the United States (US) population and $\sim 85 \%$ of the world population are positive for at least one of the six most prevalent HLA types $\left(A^{*} 02: 01, A^{*} 01: 01, A^{*} 03: 01, A^{*} 11: 01, A^{*} 24: 02\right.$, and $\left.B^{*} 07: 02\right)$ [18-20]. For many vaccines designed following such an approach the expression of the specific allele is also used as enrollment criteria for trial subjects [21-24]. However, the IRR obtained in such cancer vaccine CTs range from $\sim 15 \%$ to $100 \%$ in unpredictable fashion.

Recent technological advances in predicting HLA-binding neoepitopes from mutationderived tumor neoantigen have enabled development of more effective patient-specific therapeutic vaccines. However, also in these neoantigen vaccines, only $16-20 \%$ of the predicted neoepitopes induce $\mathrm{CD} 8^{+} \mathrm{T}$-cell responses and the majority of peptides included in the personalized vaccines proved to be false positive [25-28]. Interestingly, the CD4 ${ }^{+}$ T-cell responses were more remarkable for each vaccine. Compared with $\mathrm{CD}^{+}$killer T-cells, where the HLA-bound peptide serves as direct activation signal towards the CTL activation, $\mathrm{CD}^{+} \mathrm{T}$-cells have multiple indirect roles in vaccine-induced immune responses by enhancing the differentiation of $\mathrm{CD} 8^{+}$effector T-cells and producing Th1 cytokines facilitating the antitumor responses by e.g., recruiting macrophages and natural killer (NK) cells. Growing evidence suggests that $\mathrm{CD}^{+} \mathrm{T}$-cells also have a killing function, but this subset is not dominant [13]. However, HLA class II epitope prediction is less accurate compared to HLA class I epitope prediction, because of the highly variable epitope length (12-25 amino acids) and the enrichment of overlapping epitopes at the same protein region [29].

To overcome the limited immunogenicity of vaccine peptide selection, HLA-presented neoepitopes were predicted on the surface of the patient's tumor cells [30]. However, from 20 predicted neoepitopes only two per patient induced CD8 ${ }^{+}$T-cells (in the responder subgroup). A bioassay screening the preexisting patient-relevant neoantigen T-cell responses 
in an HLA-agnostic way improved the true positive rate of selected peptides to $59 \%$ in terms of $\mathrm{CD}^{+} \mathrm{T}$-cell responses [31]. However, neoepitope identification approaches are complex, time-consuming, and not feasible for each tumor and tumor-type [32]. Therefore, cancer vaccine development requires substantial improvement in prediction of epitopes that induce T-cell responses in individuals and consequently in larger populations (CTs) as well.

Here, we present an in silico model that is able to predict the clinical outcome of cancer vaccine CTs based on a novel immunological concept and a representative HLA-genotyped model population. This meta-analysis of almost a hundred CTs with therapeutic vaccines indicates that not only a single, but all six HLA class I alleles of individuals should be taken into consideration in relation to predicted antigen-specific immune responses.

\section{Materials and Methods}

\subsection{Studies Included in the Meta-Analysis}

The literature search was conducted between December 2016 to March 2019 in English language using PubMed and Google Scholar search engines. Peer-reviewed publications providing $\mathrm{CD}^{+} \mathrm{T}$-cell immune response and/or clinical response data were eligible for the present study. Other inclusion criteria were as follows: the vaccine antigen sequence was disclosed or otherwise available. Studies cited by the eligible articles that contained data using the same vaccine were also searched and filtered for eligibility. Eligible therapeutic vaccine types were peptide (at least nine amino acids long), nucleic acid-based, or peptide-loaded dendritic cell vaccines. Protein vaccines (whole proteins or long peptides comprising $>50$ amino acids) were excluded since those have different mechanism of action.

Studies were included if they used any of the following immunoassays: interferongamma (IFN- $\gamma$ ) ELISPOT or enzyme-linked immunosorbent assay (ELISA), MHC multimer, T-cell proliferation, intracellular cytokine staining, or cytotoxicity (killing) assays with the following restrictions: (1) in case the test antigen used for the immune response measurement was whole protein or long peptide, the data were only eligible for the analysis if the $\mathrm{CD}^{+}$phenotype of responsive cells was proven (e.g., flow cytometry or $\mathrm{CD}^{+}$T-cell depletion), (2) if more immunoassays were used, the chosen method was the one which procedure contained the fewest in vitro stimulation rounds or which the investigator used for responder identification in the publication, (3) if more than one round of in vitro stimulation was performed, the results were excluded, as stimulating multiple times can heavily bias immunoassay results. For clinical response assessment, CTs using the following standards were eligible: Response Evaluation Criteria in Solid Tumors (RECIST), World Health Organization (WHO), International Working Group (IWG), or Cancer and Leukemia Group B (CALGB) criteria [33-36]. The following exclusion criteria were used: chemotherapy combinations were excluded if their mechanism of action affected CD8 ${ }^{+}$ T-cell responses; and delayed-type hypersensitivity (DTH) assays for immunogenicity assessment. A review of abstracts identified 185 papers that were possibly relevant. Of these, 93 were excluded since they did not fulfil the pre-defined criteria described above. The remaining 92 papers, covering a total of 94 CTs were processed for further analysis and data extraction. The 94 CTs contained response data of 2338 subjects treated with 64 immunotherapeutic vaccines (63 cancer/neoplasia and one human immunodeficiency virus [HIV] vaccine), which targeted a total of 88 different antigens. Tables 1 and A1 collect the selected CTs. 
Table 1. Publications/Studies Included in the meta-analysis.

\begin{tabular}{|c|c|c|c|c|}
\hline Immunotherapy & Indication & Type & HLA Restriction & Ref. \\
\hline 9-peptide breast cancer vaccine & $\mathrm{BC}$ & Peptide & HLA-A1, -A2, or -A3 & [37] \\
\hline AFP-derived peptides & $\mathrm{aHCC}$ & Peptide & A24 & [38] \\
\hline Antigen-pulsed DC vaccine & PAdC & $\mathrm{pDC}$ & A02 & [39] \\
\hline CD34 DC vaccine & MEL & $\mathrm{pDC}$ & A02:01 & [40] \\
\hline CV9103 mRNA vaccine & PC & mRNA & no & {$[41,42]$} \\
\hline DCCP peptide vaccine & MEL & $\mathrm{pDC}$ & $\mathrm{A} 24$ or $\mathrm{A} 02$ & [23] \\
\hline DPX0907 peptide vaccine & $\mathrm{BC}, \mathrm{OC}, \mathrm{PC}$ & Peptide & A02 & {$[43,44]$} \\
\hline Elenagen pDNA vaccine & $\begin{array}{l}\text { BC, CRC, KC, LC, } \\
\text { OC, MEL }\end{array}$ & pDNA & no & [45] \\
\hline EMD640744 peptide vaccine & S.tumors & Peptide & $\begin{array}{l}\text { HLA-A1, -A2, -A3, } \\
- \text {-A24, -B7 }\end{array}$ & [22] \\
\hline Five-peptide cancer vaccine & S.tumors & Peptide & A24:02 & [46] \\
\hline GAA peptides vaccine & glioma & Peptide & A02 & {$[47,48]$} \\
\hline \multirow{3}{*}{ GL-0817 (MAGE-A3 Trojan) } & SCCHN & \multirow{3}{*}{ Peptide } & \multirow{3}{*}{ no } & [49] \\
\hline & MM & & & [50] \\
\hline & mSCCHN & & & [51] \\
\hline \multirow{2}{*}{ Glypican-3 peptide vaccine } & pediatric tumors & Peptide & $\mathrm{A} 02$ or A24:02 & {$[52]$} \\
\hline & HCC & Peptide & $\mathrm{A} 02$ or A24:02 & [53] \\
\hline GVX301 peptide vaccine & $\mathrm{PC}, \mathrm{KC}$ & Peptide & A2 & [54] \\
\hline HER1 vaccine & PC & Peptide & no & [55] \\
\hline Her2 B-cell peptide vaccine & S.tumors & Peptide & no & [56] \\
\hline Her2/neu peptide vaccine & $\mathrm{BC}, \mathrm{OC}$ & Peptide & A02 & [57] \\
\hline HIVIS & HIV positivity & pDNA & no & [58] \\
\hline \multirow{3}{*}{ HPV-SLP } & VIN3 & \multirow{3}{*}{ Peptide } & \multirow{3}{*}{ no } & [59] \\
\hline & $\mathrm{CC}$ & & & [60] \\
\hline & OrC, $\mathrm{CC}, \mathrm{AC}$ & & & [61] \\
\hline ICT107 & GB or BSG & Peptide & $\mathrm{A} 1$ or $\mathrm{A} 2$ & [62] \\
\hline $\begin{array}{l}\text { IDO and survivin peptide } \\
\text { vaccine }\end{array}$ & mMEL & Peptide & A02 & [63] \\
\hline IDO long peptide vaccine & adv. MEL & Peptide & no & [64] \\
\hline \multirow{2}{*}{ IMA901 } & RCC & \multirow[t]{2}{*}{ Peptide } & \multirow{2}{*}{ A02 } & \multirow{2}{*}[5]{} \\
\hline & mRCC & & & \\
\hline \multirow{3}{*}{ IMA950 } & AC, glioma & \multirow{3}{*}{ Peptide } & \multirow{3}{*}{ A02 } & [65] \\
\hline & AC, ODG & & & [66] \\
\hline & GB & & & [67] \\
\hline \multirow{2}{*}{ ImMucin } & MM & \multirow{2}{*}{ Peptide } & \multirow{2}{*}{ no } & [68] \\
\hline & CRC, LC, PC, TT & & & [69] \\
\hline $\begin{array}{l}\text { IMP321/LAG-3Ig + peptides } \\
\text { vaccine }\end{array}$ & mMEL & Peptide & A02 & [70] \\
\hline INGN-225 p53 vaccine & SCLC & VV & A02 & [71] \\
\hline KIF20A-66 peptide vaccine & met. $\mathrm{PaC}$ & Peptide & A24:02 & [72] \\
\hline KRM-20 vaccine & PC & Peptide & A24 & [73] \\
\hline MART-1 Peptide Vaccine & MEL & Peptide & A02 & [74] \\
\hline Melanoma peptide vaccine & MEL & Peptide or pDC & $\mathrm{A} 1,-\mathrm{A} 2$ or $-\mathrm{A} 3$ & [75] \\
\hline MELITAC 12.1 & MEL & Peptide & $\begin{array}{c}\text { A1, -A2, or -A3; } \\
\text { HLA-DR1, -DR4, } \\
\text {-DR11, -DR13, or } \\
\text {-DR15 }\end{array}$ & [24] \\
\hline Multiepitope peptide vaccine & $\mathrm{CC}$ & Peptide & A24:02 & [76] \\
\hline \multirow{2}{*}{ NY-ESO-1 OLP } & MEL, EC, LC & \multirow{2}{*}{ Peptide } & \multirow[t]{2}{*}{ no } & [77] \\
\hline & OC, FTC, PerC & & & {$[78]$} \\
\hline NY-ESO-1f & EC, GC, NSCLC & Peptide & no & [79] \\
\hline OCV-C02 vaccine & CRC & Peptide & A24:02 & [80] \\
\hline p53 SLP70-235 & CRC & Peptide & no & [81] \\
\hline
\end{tabular}


Table 1. Cont.

\begin{tabular}{|c|c|c|c|c|}
\hline Immunotherapy & Indication & Type & HLA Restriction & Ref. \\
\hline \multirow{2}{*}{ p53 SLP70-248 } & CRC & \multirow{2}{*}{ Peptide } & \multirow{2}{*}{ no } & [82] \\
\hline & EOC & & & {$[83,84]$} \\
\hline p53MVA vaccine & EOC, FTC, PerC & $\mathrm{VV}$ & no & [85] \\
\hline PepCan & CIN2/3 & Peptide & no & [86] \\
\hline Peptide cocktail therapy & $\mathrm{PaC}$ & Peptide & A24:02 w/o & [87] \\
\hline Peptide vaccine 1 & CRC & Peptide & A24:02 & [88] \\
\hline Peptide vaccine 2 & HNSCC & Peptide & A24:02 & [89] \\
\hline Peptide vaccine 3 & AML & Peptide & A02:01 & [90] \\
\hline $\begin{array}{l}\text { pNGVL4a-CRT/E7(detox) } \\
\text { vaccine }\end{array}$ & $\mathrm{CIN} 2 / 3$ & pDNA & No & [91] \\
\hline PR1 Peptide Vaccine & AML, MDS, CML & Peptide & A02 & [21] \\
\hline ProstVac & PC & $\mathrm{VV}$ & $\mathrm{A} 02$ & [92-97] \\
\hline $\begin{array}{l}\text { PSMA-Survivin pulsed } \\
\text { autologous DC vaccine }\end{array}$ & PC & $\mathrm{pDC}$ & A02:01 & [98] \\
\hline PVX-410 peptide vaccine & MM & Peptide & A02 & [99] \\
\hline RHAMM-R3 & AML & Peptide & $\mathrm{A} 02$ & [100] \\
\hline S-288310 peptide vaccine & BLC & Peptide & A24:02 & [101] \\
\hline StimuVax & NSCLC & Peptide & no & [102] \\
\hline SVN-2B peptide vaccine & GIC, BDC, $\mathrm{PaC}$ & Peptide & A24:02 & [103] \\
\hline Synchrotope TA2M & MEL & pDNA & $\begin{array}{c}\text { A02, but pts were not } \\
\text { typed }\end{array}$ & [104] \\
\hline TARP vaccine & PC & Peptide or pDC & A02:01 & [105] \\
\hline \multirow{4}{*}{ TG4010 } & cancer & \multirow{4}{*}{$\mathrm{VV}$} & no & [106] \\
\hline & PC & & no & [107] \\
\hline & RCC & & no & [108] \\
\hline & NSCLC & & no & [109] \\
\hline \multirow[t]{2}{*}{ TSPP peptide vaccine } & cancer & \multirow[t]{2}{*}{ Peptide } & \multirow[t]{2}{*}{ no } & [110] \\
\hline & $\mathrm{mCRC}$ & & & [111] \\
\hline VGX-3100 & CIN2/3 & pDNA & no & {$[112,113]$} \\
\hline \multirow{2}{*}{ Vx-001 } & S.tumors & \multirow{2}{*}{ Peptide } & \multirow{2}{*}{ А $02: 01$} & {$[114,115]$} \\
\hline & NSCLC & & & {$[116,117]$} \\
\hline \multirow{3}{*}{ WT1 vaccine (1) } & glioma & Peptide & A24:02 & [118] \\
\hline & $\mathrm{PaC}$ & \multirow{2}{*}{$\mathrm{pDC}$} & \multirow{2}{*}{ A24:02 } & [119] \\
\hline & $\mathrm{BC}, \mathrm{OC}, \mathrm{GC}$ & & & [120] \\
\hline WT1 peptide vaccine & AML MDS & Peptide & A02 & [121] \\
\hline WT1 peptides & $\mathrm{PaC}$ & Peptide & A02:01 or A24:02 & {$[122]$} \\
\hline WT1 vaccine (2) & $\mathrm{mPM}$ & Peptide & no & [123] \\
\hline
\end{tabular}

Abbreviations: DC: dendritic cell, AFP: Alpha-fetoprotein, HPV: human papilloma virus, SLP: synthetic long peptide, IDO: Indoleamine 2,3-Dioxygenase, MART1: melanoma antigen recognized by T-cells 1, NY-ESO-1: New York Esophageal Squamous Cell Carcinoma-1, MVA: Modified vaccinia Ankara, PSMA: prostate-specific membrane antigen, RHAMM: receptor for hyaluronic acid mediated motility, TARP: T-cell receptor alternate reading frame protein, TSPP: Thymidylate synthase poly-epitope peptide, WT1: Wilms Tumor Protein 1, PAdC: adenocarcinoma of the pancreas, aHCC: advanced hepatocellular carcinoma, PC: prostate cancer, BC: breast cancer, OC: ovarian cancer, EOC: epithelial ovarian cancer, CRC: colorectal cancer, KC: kidney cancer, pDNA: plasmid DNA, mSCCHN: metastatic squamous cell carcinoma of the head and neck, MM: multiple myeloma, RCC: renal cell carcinoma, CC: cervical cancer, VIN: vaginal intraepithelial neoplasia, GB: glioblastoma, AC: astrocytoma, ODG: oligodendroglioma, SCLC: small cell lung cancer, NSCLC: non-small cell lung cancer, PaC: pancreatic cancer, MEL: melanoma, BSG: brainstem glioma, TT: testicular tumors, EC: esophageal cancer, FTC: fallopian tube carcinoma, PerC: carcinoma of the peritoneum, GC: gastric cancer, CIN: cervical intraepithelial neoplasia, AML: acute myeloid leukemia, MDS: myelodysplastic syndrome, BLC: bladder cancer, GIC: gastrointestinal cancer, BDC: bile duct cancer, OrC: oropharyngeal, AC: anal cancer, pDC: peptide-pulsed dendritic cell, S.tumors: solid tumors, VV: viral vector-based vaccine, mPM: malignant pleural mesothelioma.

IRR is the proportion of subjects in the study population who had in vitro CD8 ${ }^{+}$ T-cell responses induced by the study vaccine as reported in the publications. CRR is the proportion of subjects in the study population who had clinical response (partial or 
complete in terms of tumor shrinkage for solid tumors and reduction in M-component level or myeloblasts in the bone marrow for hematological tumors) after vaccination as reported in the publications (Table A1).

\subsection{In Silico Trial}

The in silico trial is based on the cohort of 433 subjects, called Model Population (MP). Each subject in the MP has complete four-digit HLA class I genotype (all six alleles) information available. The MP was assembled from three sources: (i) 270 subjects from the HapMap collection, including 90 Yoruban, 90 European, 45 Chinese, and 45 Japanese subjects [124], (ii) 67 subjects from the European Searchable Tumour Line Database (ESTDAB) database [125], including subjects from US, Canada, Australia, and New Zealand, and (iii) 96 subjects from the HIV database [126].

Epitope predictions were performed using Immune Epitope Database (IEDB) recommended setting that uses consensus approach $[127,128]$. The vaccine antigens were scanned with overlapping 9-mer peptides to identify epitopes that bind to any of a MP-subject's six HLA class I alleles. These predictions were performed for each of the 433 subjects in the MP.

During the in silico modelling, predicted frequency of vaccine-specific HLA-binding epitopes were used to calculate the in silico IRRs for the MP (see also Table 2):

Table 2. Parameters used in the correlative studies.

\begin{tabular}{|c|c|c|c|c|}
\hline \multicolumn{5}{|c|}{ Predicted Percentage of Subjects in the MP: } \\
\hline Parameters & $\begin{array}{l}\text { Number of Vaccine-Specific } \\
\text { Epitopes }\end{array}$ & $\begin{array}{c}\text { Number of Vaccine-Specific } \\
\text { Proteins }\end{array}$ & $\begin{array}{l}\text { Threshold of HLA Alleles } \\
\text { Binding the Epitope }(n)\end{array}$ & Analysis Performed \\
\hline In Silico IRR $(n \times$ HLA) & $\geq 1$ & $\geq 1$ & $\geq 1, \geq 2, \geq 3$ or $\geq 4$ & $\begin{array}{l}\text { Measured and predicted IRR } \\
\text { correlations }\end{array}$ \\
\hline $\begin{array}{c}\text { In Silico multi-epitope IRR ( } n \\
\times \text { HLA) }\end{array}$ & $\geq 2$ & $\geq 1$ & $\geq 1, \geq 2, \geq 3$ or $\geq 4$ & $\begin{array}{l}\text { Measured and predicted CRR } \\
\text { correlations }\end{array}$ \\
\hline $\begin{array}{l}\text { In Silico multi-Ag IRR }(n \times \\
\text { HLA })\end{array}$ & $\geq 2$ & $\geq 2$ & $\geq 1, \geq 2, \geq 3$ or $\geq 4$ & $\begin{array}{l}\text { Measured and predicted CRR } \\
\text { correlations }\end{array}$ \\
\hline
\end{tabular}

In Silico IRR $(1 \times$ HLA): the percentage of subjects in the MP with $\geq 1$ vaccine-specific epitope binding to at least one autologous HLA class I allele.

In Silico IRR $(2 \times \mathrm{HLA})$ : the percentage of subjects in the MP with $\geq 1$ vaccine-specific epitope binding to at least two autologous HLA class I alleles.

In Silico IRR $(3 \times$ HLA): the percentage of subjects in the MP with $\geq 1$ vaccine-specific epitope binding to at least three autologous HLA class I alleles.

In Silico IRR $(4 \times$ HLA): the percentage of subjects in the MP with $\geq 1$ vaccine-specific epitope binding to at least four autologous HLA class I alleles.

In Silico multi-epitope IRR $(1 \times \mathrm{HLA})$ : the percentage of subjects with $\geq 2$ vaccinespecific epitopes binding to at least one autologous HLA class I allele.

In Silico multi-epitope IRR $(2 \times \mathrm{HLA})$ : the percentage of subjects with $\geq 2$ vaccinespecific epitopes binding to at least two autologous HLA class I alleles.

In Silico multi-epitope IRR $(3 \times$ HLA): the percentage of subjects with $\geq 2$ vaccinespecific epitopes binding to at least three autologous HLA class I alleles.

In Silico multi-epitope IRR $(4 \times \mathrm{HLA})$ : the percentage of subjects with $\geq 2$ vaccinespecific epitopes binding to at least four autologous HLA class I alleles.

In Silico multi-Ag IRR $(1 \times \mathrm{HLA})$ : the percentage of subjects with $\geq 2$ vaccine-specific epitopes originated from different protein antigens targeted by the vaccine and binding to at least one autologous HLA class I allele.

In Silico multi-Ag IRR $(2 \times \mathrm{HLA})$ : the percentage of subjects with $\geq 2$ vaccine-specific epitopes originated from different protein antigens targeted by the vaccine and binding to at least two autologous HLA class I allele. 
In Silico multi-Ag IRR $(3 \times \mathrm{HLA})$ : the percentage of subjects with $\geq 2$ vaccine-specific epitopes originated from different protein antigens targeted by the vaccine and binding to at least three autologous HLA class I allele.

In Silico multi-Ag IRR $(4 \times \mathrm{HLA})$ : the percentage of subjects with $\geq 2$ vaccine-specific epitopes originated from different protein antigens targeted by the vaccine and binding to at least four autologous HLA class I allele.

When the vaccine was intended for a specific subpopulation (HLA preselection), the MP was also stratified to the same specific subgroup (e.g., only HLA-A*0201 positive patients were enrolled, see Table 1 ). When the immunogenicity of a multi-peptide vaccine was measured and published per peptide, the in silico IRRs were also determined per peptide. When there were more than one study published for the same vaccine with the same HLA restriction, the cohorts of the studies were combined and RRs were calculated for the combined population (sum of responders for all trials/sum of total analyzed subjects in all trials, see Table A1).

These in silico IRRs were compared with the published IRRs and/or CRRs determined in the CTs.

\subsection{Statistical Calculations}

Representativeness of the MP was assessed by comparison of the summed allele set (152 different alleles) frequency of the MP with the summed frequency of the 4818 HLA alleles contained in the Catalog of common, intermediate and well-documented HLA alleles (CIWD) based on $>8$ million subjects' HLA background [129]. Epitope binding capabilities were compared with a 16,000 subject cohort (National Marrow Donor Program, NMDP cohort, see below) and were evaluated as follows: from the collected 94 CTs the 11 most frequently used target proteins were selected, which together spanned 5434 amino acids in length and included 5346 possible 9-mers. For both the MP and the NMDP cohort for each protein's each amino acid the proportion of subjects who are able to bind an epitope (9-mer) starting at that position with $\geq 1, \geq 2, \geq 3, \geq 4, \geq 5$ or all six HLA alleles were determined. For each HLA cut-off these frequencies for each amino acid position (MP versus NMDP cohort) were plotted. Correlation was determined by Pearson correlation coefficient ( $r$ ), and statistical significance was computed following the Student's t-distribution with degree of freedom $n-2$, with a significance threshold of $p<0.05$. Epitope predictions were performed as described for the in silico trial $[127,128]$.

The 16,000 subjects' (NMDP cohort) HLA genotype data were obtained from the US National Marrow Donor Program [130]. This cohort of US origin covered 16 ethnic groups, with 1000 subjects in each: African, African American, Asian Pacific Islander, Filipino, Black Caribbean, Caucasian, Chinese, Hispanic, Japanese, Korean, Native American Indian, South Asian, Vietnamese, US, Mideast/North coast of Africa, Hawaiian, and other Pacific Islander.

For the measured and predicted response rates, correlations were assessed using the Pearson correlation coefficient $(r)$, measuring linear correlation between two variables. A general trend line was used to compute confidence interval bands with level 0.95 probability and to predict interval bands with level of 0.95 probability. A perpendicular line was used to show the trend between the predicted and clinical outcome. This linear regression is based on the line that has the minimum perpendicular distance-squares from the points. Statistical significance was computed following the Student's t-distribution with degree of freedom $n-2$.

Pairwise comparison of measured and predicted response rates were done using an online tool that is based on the " $n-1$ " Chi-squared test as recommended by others [131-134]. Each data pair (measured and predicted response rate) were separately entered into the calculator together with the respective sample sizes. Difference between a measured and predicted data pair was considered significant when $p<0.05$.

Receiver operating characteristic (ROC) area under the curve (AUC) was calculated based on the traditional $2 \times 2$ contingency table assembled using the following assumptions: (1) to obtain a binary classification, AUC was calculated for each IRR in the range of 30-80\% 
to avoid imbalanced dataset, (2) in silico IRR data points were classified as true negative (TN), true positive (TP), false positive (FP), false negative (FN) based on the threshold, (3) sensitivity $(\mathrm{TP} /(\mathrm{TP}+\mathrm{FN}))$ and specificity $(\mathrm{TN} /(\mathrm{TN}+\mathrm{FP}))$ were calculated based on the $2 \times 2$ contingency table. To obtain the ROC curve, sensitivity was plotted against the 1-specificity and the AUC was calculated [135].

\section{Results}

\subsection{Preselection of HLA-Matched Subjects Does Not Improve Response Rate Obtained in Clinical Trials}

To study the parameters likely affecting the IRR and CRR of CTs, a meta-analysis of the immunological and clinical results reported in 94 CTs involving 2338 subjects treated with 64 immunotherapeutic vaccines targeting 88 different antigens were performed (Tables 1 and A1). No significant difference was found between the IRRs of CTs preselecting the trial subjects based on their HLA alleles $(n=52 \mathrm{CTs})$ or accepting "all-comers" $(n=25 \mathrm{CTs})$ without HLA determination (median $60 \%$ vs. $57 \%, p=0.4490$ ) (Figure 1a).

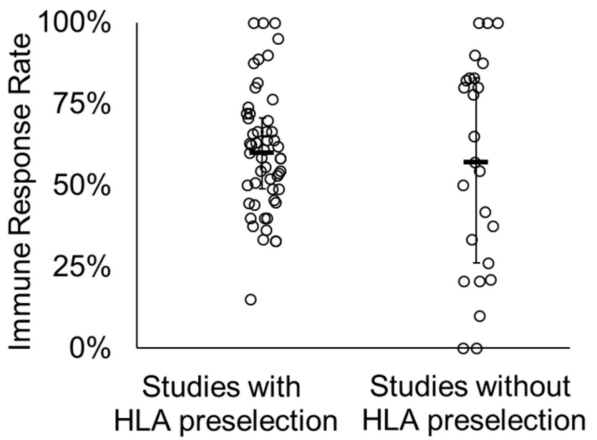

(a)

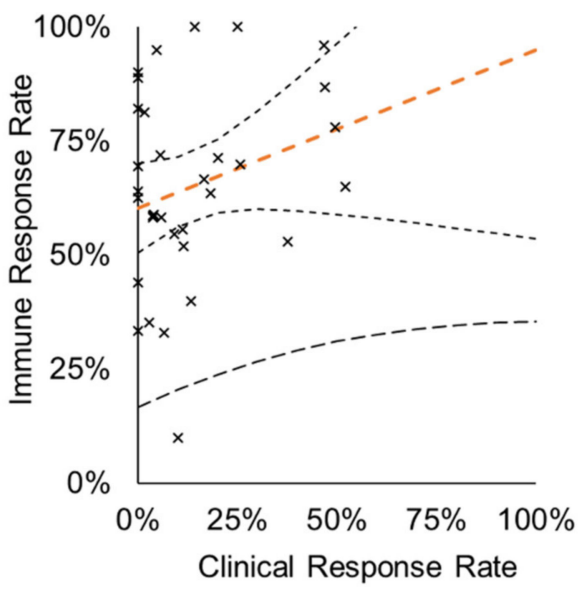

(c)

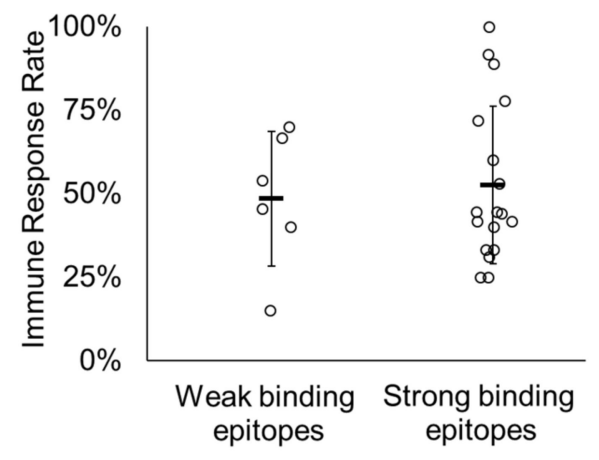

(b)

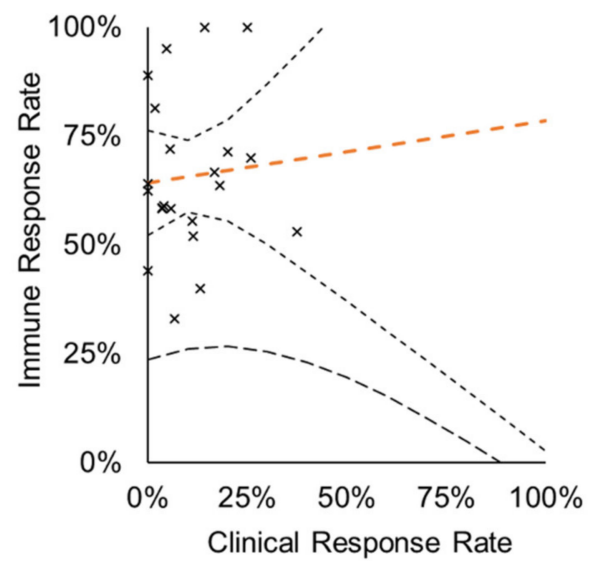

(d)

Figure 1. Immunogenicity of cancer vaccines is not predictive for efficacy. (a) IRR of CTs with $(n=52)$ or without $(n=25)$ HLA preselection of subjects. Medians (marked with horizontal line) were $60 \%$ and $57 \%$, respectively $(p=0.4490)$. Each mark represents one CT. Error bars represent the standard deviation of the datasets. (b) IRR of CTs does not correlate with predicted binding affinity of vaccine epitopes. Strong $(n=18)$ and weak $(n=6)$ binding epitopes were grouped based on the predicted binding affinity to the HLA allele used for subject preselection. Strong binders are epitopes with $<2$ IEDB percentile rank $(p=0.6657)$. Each mark represents one peptide. (c) IRR of vaccines does not correlate with clinical responses $(r=0.2594, p=0.1495)$. Forty-two CTs of 33 vaccines were used in the analysis. (d) IRR of vaccines does not correlate with CRR in CTs where subjects are preselected based on HLA $(r=0.0782, p=0.7293)$. Twenty-nine CTs of 28 vaccines were used in the analysis. Orange dashed line: perpendicular trend line with $95 \%$ confidence interval bands $(95 \%$ prediction interval band is shown by thicker dashed line). Each mark represents one CT. 
This suggests that the presence of a matching HLA allele does not ensure the generation of $\mathrm{CD}^{+} \mathrm{T}$-cell responses (immune responses) upon vaccination, thus it is not a valid predictor. In order to investigate whether the predicted binding affinity of an epitope included in a vaccine has major impact on the IRR, we selected those CTs where the CD8 ${ }^{+}$ T-cell responses were reported for individual short peptides (9- or 10-mers) and the CT included the HLA preselection of the subjects. Fourteen CTs were eligible for such analysis, conducted with 13 vaccines covering a total of 24 peptides. No significant difference was found between the IRRs of strong binder ( $<2$ percentile rank) and weak binder ( $>2$ percentile rank) vaccine epitopes (average 53\% and $49 \%$, respectively, $p=0.6657$ ) (Figure $1 \mathrm{~b}$ ). Due to the high standard deviation in both groups, applying more strict thresholds for the separation of strong- and weak-binder epitopes (at $<0.5$ or $<1$ percentile rank) also results in non-significant differences between the IRRs of the two groups (data not shown). This result supports the earlier finding that not only those epitopes are able to elicit immune response which are predicted as strong binders [30].

As expected, there was no correlation between the IRR and CRR reported for the studies $(r=0.2594)$, nor for the trials employing HLA preselection $(r=0.0782)$ (Figure $1 c, d)$.

\subsection{Characterization of the In Silico Model}

\subsubsection{HLA Allele Frequency Analysis}

Based on the results obtained in Figure 1a the criterion of a single HLA-match does not seem to be sufficient to predict the immunogenicity of vaccines. To overcome this we hypothesized that all six HLA alleles of a person could contribute to the generation of in vitro measured CD8 ${ }^{+}$T-cell responses, not only one of them. Therefore, the model was built on complete HLA genotype of individuals allowing to study the effect of the combination of all six HLA class I alleles. Since complete HLA genotype data of the subjects participating in the CTs were not available, a model cohort (MP) was built of 433 subjects with four-digit HLA class I genotype covering multiple ethnicities (see Materials and Methods). The representativeness of the MP was assessed by comparing the HLA allele coverage to the latest collection of allele frequencies included in the Catalog of common, intermediate and well-documented alleles (CIWD), which was compiled based on $>8$ million subjects' HLA background [129]. The summed frequency of the 4818 HLA class I alleles included in the CIWD is considered as 1.00 (or 100\%). Compared to this, the 152 HLA class I alleles covering the 433 subjects in the MP (Table A2) have a summed frequency of 0.974 (or $97.4 \%$ ). This means that these 152 alleles are the most frequently occurring globally, and the remaining 4666 alleles are rare alleles (2.6\%). Specific HLA-selected subpopulations of the MP used in the study also reach at least $89 \%$ coverage calculated following the same methodology (Table S1). Therefore, the likelihood that a person in a CT would have one or more of the rare alleles not covered by this set is low.

\subsubsection{Epitope-Binding Capabilities}

Since the aim was to consider the combination of HLA alleles within a person, the representativeness of the MP was assessed also on this level. The search for databases or publications to find reference data for frequent HLA allele combinations/HLA genotypes was unsuccessful, thus as reference population a large cohort of 16,000 subjects with complete HLA genotype (NMDP cohort, see Methods) was chosen. As a comparison to the MP, this cohort has 497 different HLA class I alleles with a summed frequency of 0.998 (similar analysis as above). To prove that the epitope-binding capabilities of the HLA allele combinations of MP correlate with the ones of the large 16,000 subject population, epitope mapping was performed for the 11 most frequently used vaccine proteins based on the collected dataset. For all 11 proteins' each possible 9-mer the frequency of subjects was determined in the MP and in the NMDP cohorts, who were predicted to bind the specific epitope by at least 1, 2, 3, 4, 5, or all 6 of their HLA alleles. Figure 2a shows the correlation plots obtained for the six HLA cut-offs, each demonstrating strong correlation 
( $p<10^{-39}$ and $\mathrm{r}$ of $\left.0.874-0.991\right)$ between the epitope-binding capability of the MP and the NMDP cohorts.

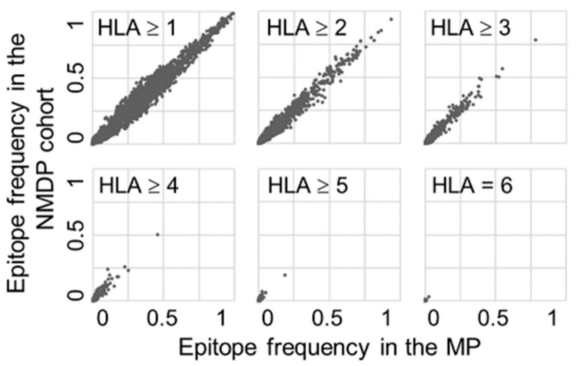

(a)

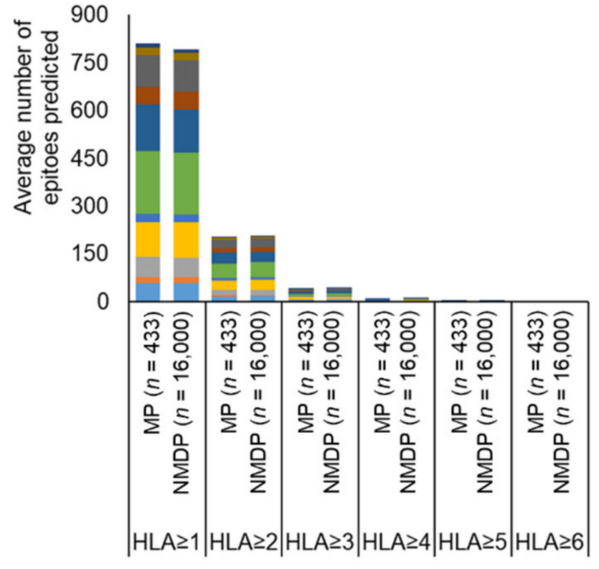

(b)

Figure 2. Representativeness of the in silico model cohort (MP) demonstrated by the correlation of epitope-binding capabilities with the NMDP cohort of 16,000 subjects. (a) Frequency of MP versus NMDP cohort subjects predicted to bind 9-mers of the 11 protein antigens for the six different cut-offs: HLA $\geq 1$ alleles $\left(r=0.9897, p<10^{-102}\right)$, HLA $\geq 2$ alleles $(r=$ $\left.0.9903, p<10^{-102}\right)$, HLA $\geq 3$ alleles $\left(r=0.9849, p<10^{-102}\right)$, HLA $\geq 4$ alleles $\left(r=0.9611, p<10^{-102}\right)$, HLA $\geq 5$ alleles $(r=$ $\left.0.9401, p=4.7 \times 10^{-102}\right)$, or HLA $=6$ alleles $\left(r=0.8742, p=1.8 \times 10^{-39}\right)$. Each point represents a possible 9-mer epitope of the selected 11 protein antigens. (b) Average number of epitopes predicted for the six different cut-offs: binding to $\geq$

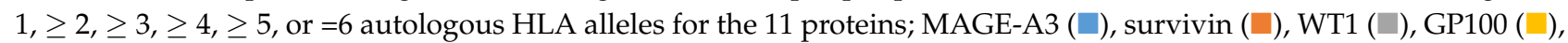

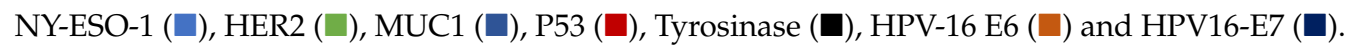

The average number of epitopes binding to at least 1, 2, 3, 4, 5, or all 6 HLA alleles for these 11 proteins was also compared between the two populations, which was found to be similar (Figure $2 b$ ). This analysis also shows that a fraction of epitopes (25-26\%) are able to bind multiple $(\geq 2)$ HLA alleles of a subject, potentially supporting the relevance of our hypothesis. The average number of epitopes for a person that bind at least 5 HLA alleles is so small ( $<0.3$ epitopes) that the $\geq 5$ HLA and $=6$ HLA cut-offs were not further investigated in the present study. Based on these results the MP was considered representative in terms of HLA allele frequency and epitope-binding capability of the HLA-sets (HLA genotypes) for the cohorts involved in the CTs of this study.

\subsection{In Silico IRRs in the MP Correlate with IRRs Measured in CTs}

\subsubsection{Correlation Analysis between In Silico and Measured IRRs}

Next, we aimed to demonstrate that predicted multiple autologous HLA allele-binding epitopes better characterize the IRR of therapeutic vaccines. To achieve this, in silico IRRs were determined by calculating the proportion of subjects in the MP having at least one vaccine-specific epitope that is predicted to bind $\geq 1, \geq 2, \geq 3$ or $\geq 4$ autologous HLA class I alleles (In Silico IRR $(1 \times$ HLA), In Silico IRR $(2 \times$ HLA), In Silico IRR $(3 \times$ HLA), In Silico IRR $(4 \times$ HLA), respectively, see also Materials and Methods and Table 2). Of note, IRR of the clinical studies is usually reported for T-cell responses measured against at least one epitope (a peptide or a peptide pool), therefore this criterion was used in this study as well. In the analysis $79 \mathrm{CT}$ s conducted with 55 vaccines, resulting in 59 data points were included. Analysis revealed that single HLA allele binding epitopes (cut-off HLA $\geq 1$ ) highly overestimated the measured IRRs as more than $80 \%$ of the CTs were predicted to have at least one epitope restricted to at least one HLA allele of each of the 433 subjects $(100 \%$ In Silico IRR $(1 \times$ HLA $))$, therefore the correlation was weak $(r=0.3225, p=0.0127)$ (Figure 3a). 


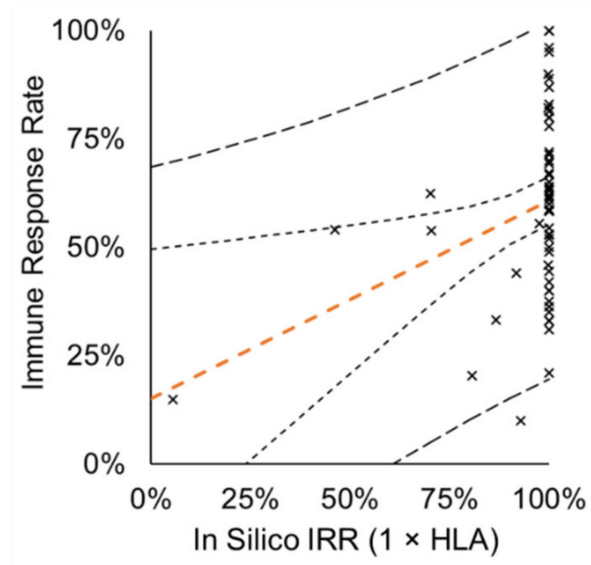

(a)

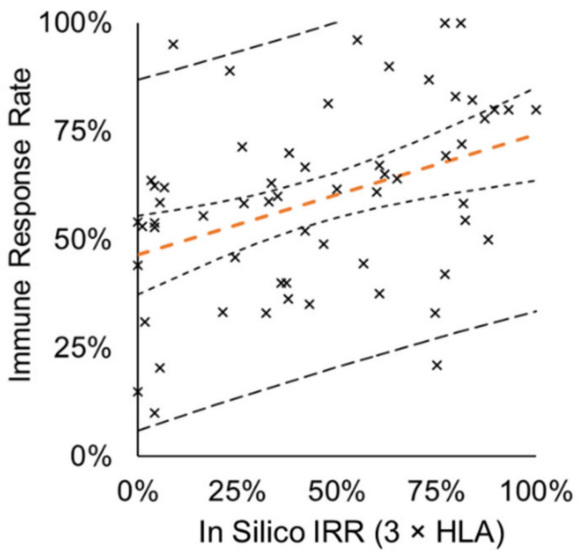

(c)

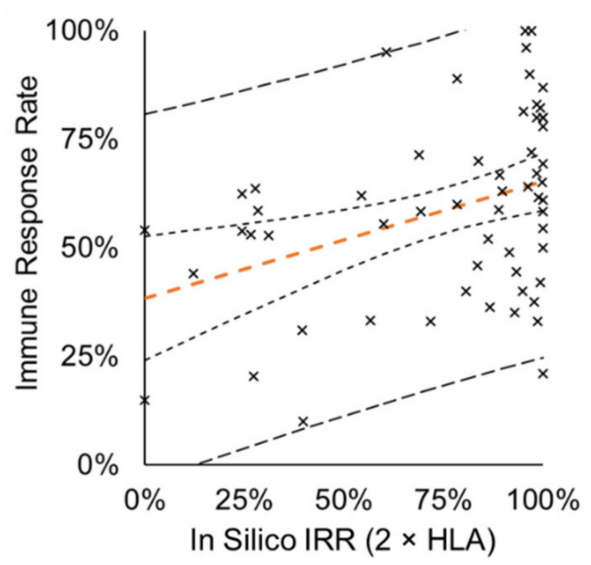

(b)

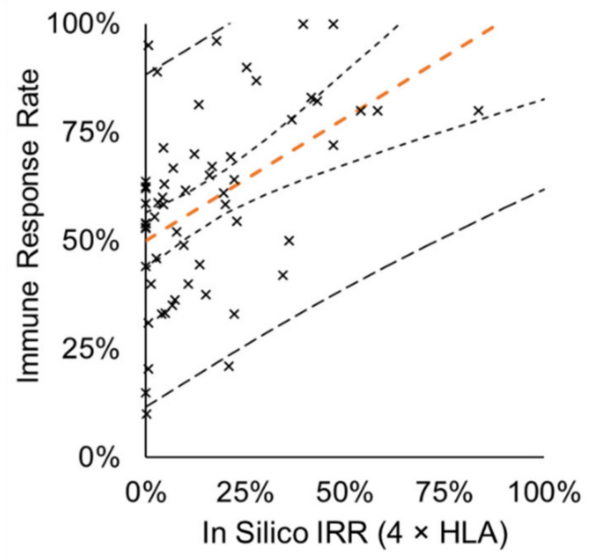

(d)

Figure 3. Correlation analysis between in silico and measured IRRs. In silico prediction was based on the proportion of subjects in the MP having at least one vaccine-specific epitope that is (a) restricted to $\geq 1$ autologous HLA class I allele $(r=0.3225, p=0.0127),(\mathbf{b})$ restricted to $\geq 2$ autologous HLA class I alleles $(r=0.3763, p=0.0033),(\mathbf{c})$ restricted to $\geq 3$ autologous HLA class I alleles $(r=0.4015, p=0.0016)$, (d) restricted to $\geq 4$ autologous HLA class I alleles $(r=0.4780, p=$ 0.0001). Analysis included 59 data pairs covering 79 CTs with 55 vaccines. Orange dashed line: perpendicular trend line with $95 \%$ confidence interval band ( $95 \%$ prediction interval band is shown by thicker dashed line).

A similar shift of points can be observed for In Silico IRR $(2 \times$ HLA $)(r=0.3763$, $p=0.0033)$ with a less marked pattern (Figure $3 b)$. In Silico IRR $(3 \times$ HLA) shows a more balanced distribution of the data pairs indicating substantial relationship between the frequency of the epitopes restricted to at least three autologous HLA alleles and IRRs measured in the CTs $(r=0.4015, p=0.0016)$ (Figure 3c). Similarly, for the In Silico IRR $(4 \times$ HLA) moderate correlation ( $r=0.4780, p=0.0001$ ) was observed with the IRRs (Figure 3d) and a tendency to underestimate IRRs (points shifted towards left), opposite to In Silico IRR $(1 \times$ HLA $)$ and In Silico IRR $(2 \times$ HLA $)$.

ROC curve analysis confirmed the association between in vitro-measured IRR and the frequency of the multiple autologous allele-binding epitopes (in silico IRRs). The area under the ROC curve (AUC) for each IRR threshold (in the 30\% to $80 \%$ interval) was in the range of 0.63-0.79, indicating fair/good accuracy [136] of the prediction independent of chosen IRR thresholds (Figure 4a and Table S2). 


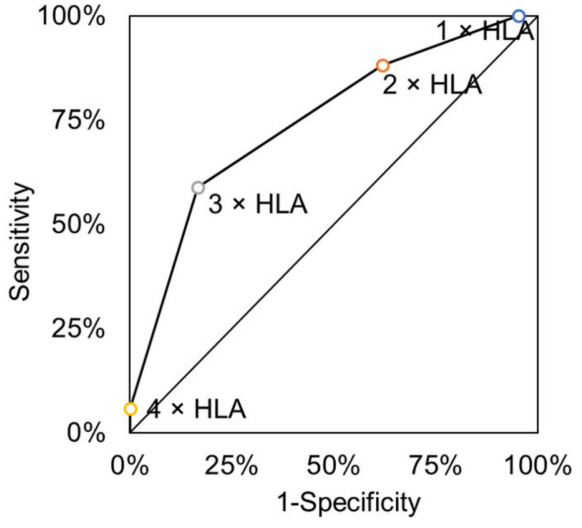

(a)

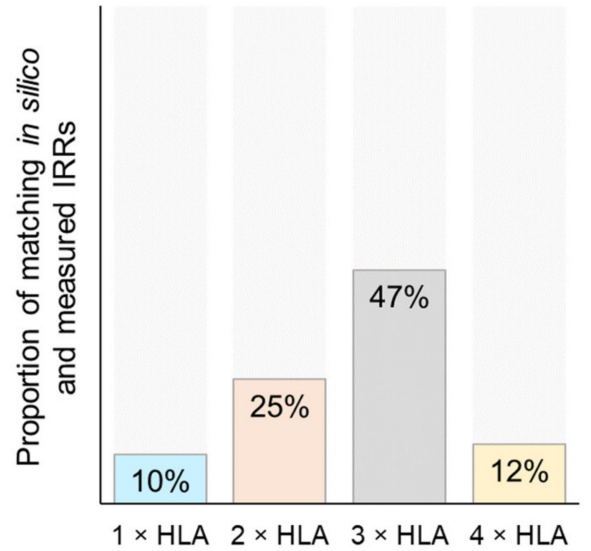

(b)

Figure 4. Performance evaluation of the in silico trials. (a) Example of a Receiver Operating Characteristic (ROC) curve of the in silico IRR predictions when the success threshold is considered as $\geq 70 \%$ IRR (AUC $=0.75$ ) (related to Table S2). (b) Pairwise Chi square analysis of measured and predicted IRRs; bars represent the proportion of the analyzed data pairs where difference was not significant $(p>0.05)$. Analyzed dataset was the same as used for Figure 3 ( 59 data pairs covering 79 CTs with 55 vaccines).

\subsubsection{Pairwise Comparison of In Silico and Measured IRRs}

Pairwise Chi square analysis revealed that In Silico IRR $(1 \times$ HLA $)$ correctly predicted IRR for only $10 \%(6 / 59)$ of the analyzed data pairs (no significant difference between measured and in silico predicted IRR values, $p>0.05)$, while this proportion was the highest, 47\% (28/59), for In Silico IRR (3 × HLA) (Figure 4b).

Pairwise analysis was also performed by grouping the data pairs based on vaccine type: peptide vaccines (46 data pairs), dendritic cell (DC) vaccines (4 data pairs), and nucleic acid vaccines, covering plasmid DNA, viral vector and mRNA vaccines ( 9 data pairs). As expected based on the majority of peptide vaccines in the dataset, the proportions of matching results obtained for peptide vaccines were similar with the combined dataset shown in Figure 4b: 13\%, 33\%, 43\% and 7\% for the HLA thresholds $\geq 1-4$, respectively (Figure S1). The separate evaluation of DC vaccines and nucleic acid-based vaccines also show the superiority of HLA $\geq 3$ threshold; however these results should be interpreted with caution due to the low number of data pairs (Figure S1).

These results suggest that the multiple autologous HLA allele-binding concept outperforms the conventional single-HLA allele-binding approach and the in silico IRRs as determined by the model are able to retrospectively estimate immunogenicity of the therapeutic vaccines.

\subsection{Relationship between Immune- and Clinical Response}

\subsubsection{Vaccines Targeting Multiple Epitopes}

As previously suggested, subjects having broader immune responses (against multiple vaccine-specific epitopes) may experience clinical benefit, therefore the relationship between the in silico IRRs and clinical responses was next examined. As a measure of vaccines' ability to induce broad immune responses, the in silico IRRs against multiple epitopes were calculated for each HLA threshold; the percentage of subjects in the MP with $\geq 2$ vaccine-specific epitopes binding to $\geq 1, \geq 2, \geq 3$ or $\geq 4$ autologous HLA class I alleles (In silico multi-epitope IRR $(1 \times$ HLA), In silico multi-epitope IRR $(2 \times$ HLA $)$, In silico multi-epitope IRR $(3 \times$ HLA), In silico multi-epitope IRR $(4 \times \mathrm{HLA})$, respectively). This analysis included 38 data pairs of 49 CTs conducted with 31 vaccines (Table A1). Using the Pearson correlation analysis no correlation was found between CRR and any of the in silico multi-epitope IRRs (Figure 5a-d). 


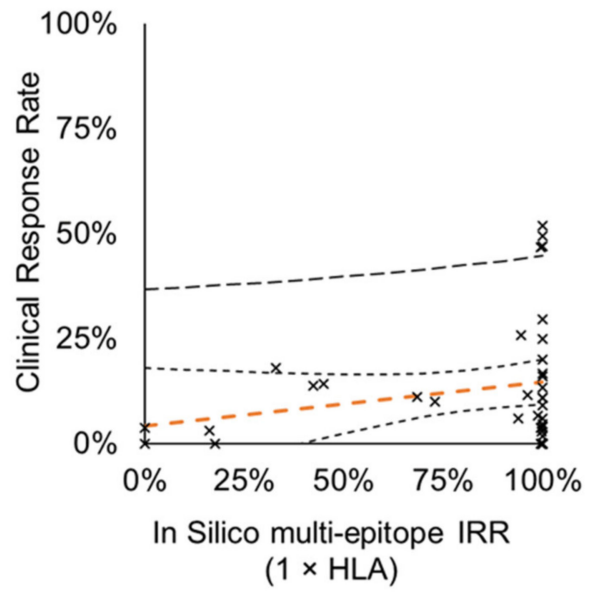

(a)

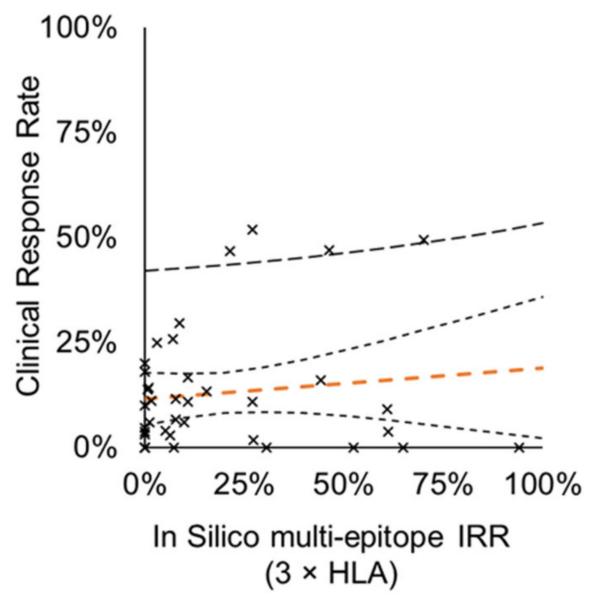

(c)

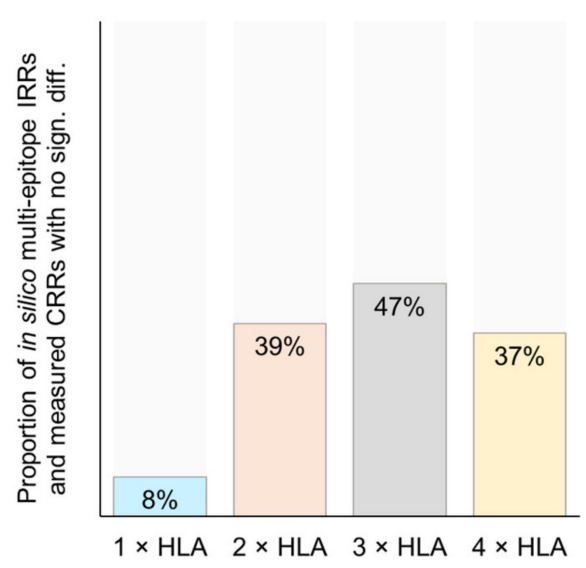

(e)

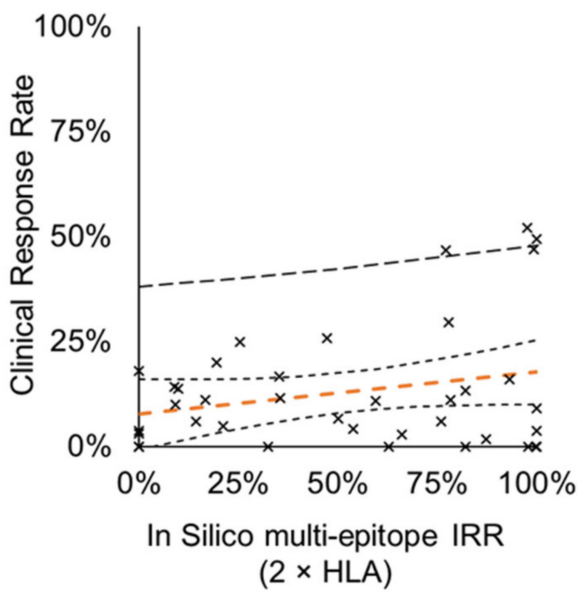

(b)

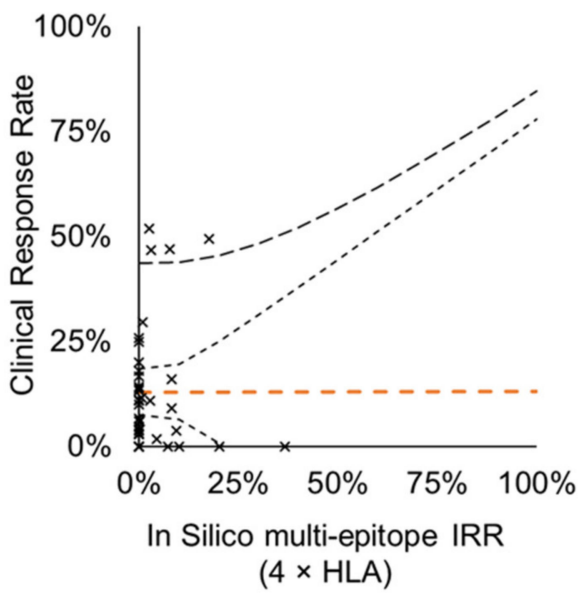

(d)

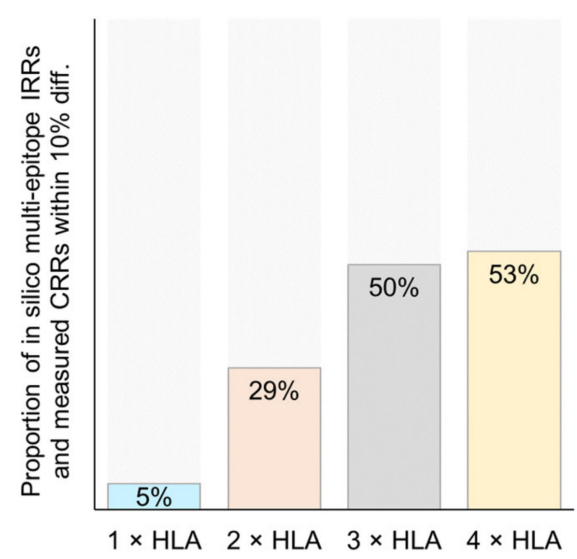

(f)

Figure 5. Correlation analysis between CRRs measured by CTs and in silico multi-epitope IRRs with cut-offs HLA $\geq 1, \geq 2$, $\geq 3$, or $\geq 4$ in the MP. Analysis included 49 CTs with 31 vaccines, total of 38 data points. Prediction of multi-epitope IRRs required the presence of at least two vaccine-specific epitopes that are (a) restricted to $\geq 1$ autologous HLA class I allele ( $r=0.2233$, $p=0.1777)$, (b) restricted to $\geq 2$ autologous HLA class I alleles $(r=0.2520, p=0.1269)$, (c) restricted to $\geq 3$ autologous HLA class I alleles $(r=0.1253, p=0.4536)$, (d) restricted to $\geq 4$ autologous HLA class I alleles $(r=0.0003, p=0.9985)$ of the subjects in the MP, respectively. Orange dashed line: perpendicular trend line with $95 \%$ confidence interval band (95\% prediction interval band is shown by thicker dashed line). (e,f) Pairwise Chi square analysis of measured CRRs and predicted multi-epitope IRRs; bars represent the proportion of the analyzed data pairs where difference was (e) not significant $(p>0.05)$, or (f) within $10 \%$. 
Again, the datasets were analyzed pairwise for each HLA threshold to make a point by point comparison of predicted and measured data. When assessing the significance of the differences obtained for the data pairs, the most non-significantly different pairs $(18 / 38$, $47 \%$ ) were obtained again with the $\geq 3$ HLA threshold (Figure 5e). The other multi-HLA cut-offs also performed fairly in predicting CRRs ( $39 \%$ for $2 \times$ HLA and $37 \%$ for $4 \times$ HLA). Specifically, $\geq 50 \%$ of the data pairs were found to be within $10 \%$ difference for HLA $\geq 3$ and HLA $\geq 4$ cut-offs (Figure 5f). While for the single HLA allele-restricted epitopes $(1 \times$ HLA) the in silico multi-epitope IRRs matched the CRRs in only $8 \%$ of cases (Figure $5 e$ ).

Similar to the IRR analysis, we investigated the pairwise agreement in subgroups of vaccine types: peptide vaccines (30 data pairs), DC vaccines (3 data pairs), and nucleic acid vaccines, covering plasmid DNA and viral vector vaccines ( 6 data pairs). Again because of the dominance of peptide vaccines among the data pairs the result was comparable to the combined analysis shown in Figure 5e, and reinforced for other vaccine types, too (Figure S2).

\subsubsection{Vaccines Targeting Multiple Protein Antigens}

Another measure for the breadth of immune responses may be the percentage of subjects with $\geq 2$ vaccine-specific epitopes originated from different protein antigens targeted by the vaccine, i.e., multi-antigenic IRR. These in silico IRRs were computed for each HLA threshold (In silico multi-Ag IRR $(1 \times$ HLA), In silico multi-Ag IRR $(2 \times$ HLA), In silico multi-Ag IRR $(3 \times$ HLA $)$, In silico multi-Ag IRR $(4 \times$ HLA $))$ and compared with the CRRs measured in the CTs (Figure 6a-d).

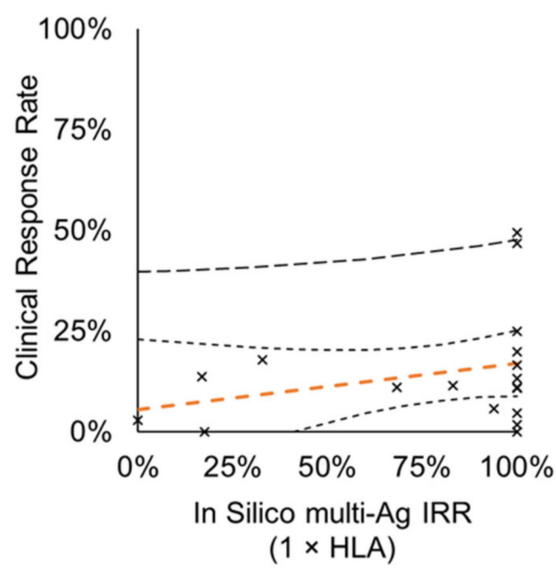

(a)

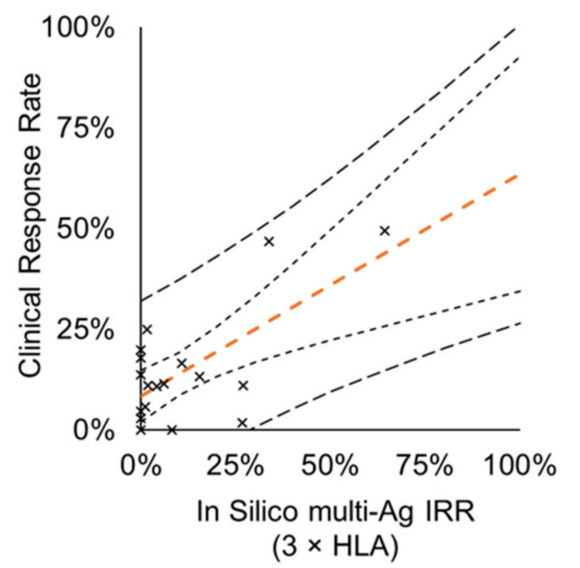

(c)

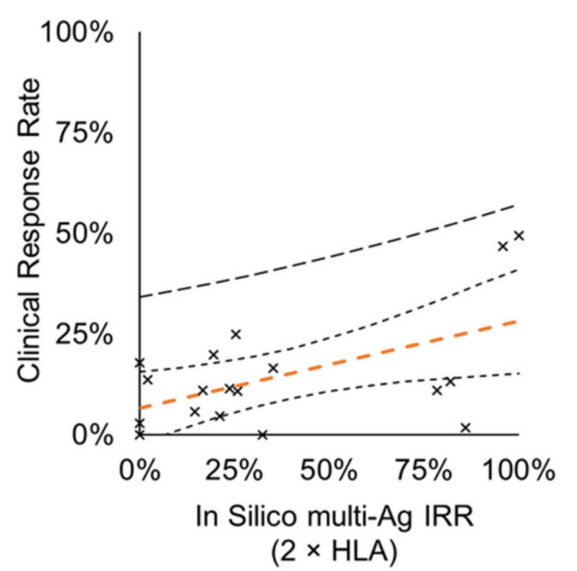

(b)

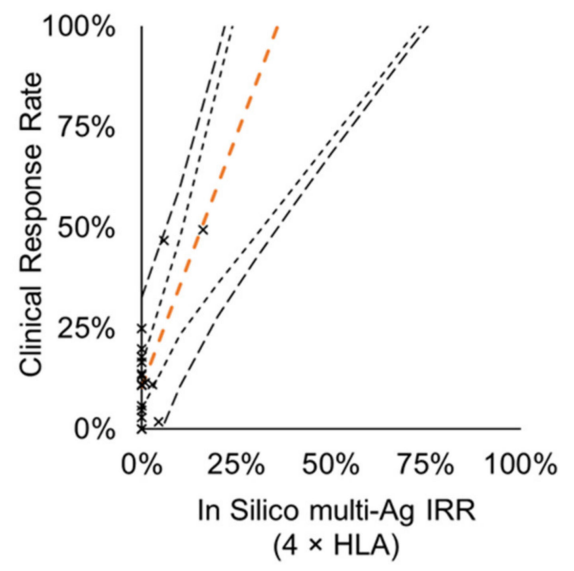

(d)

Figure 6. Cont. 


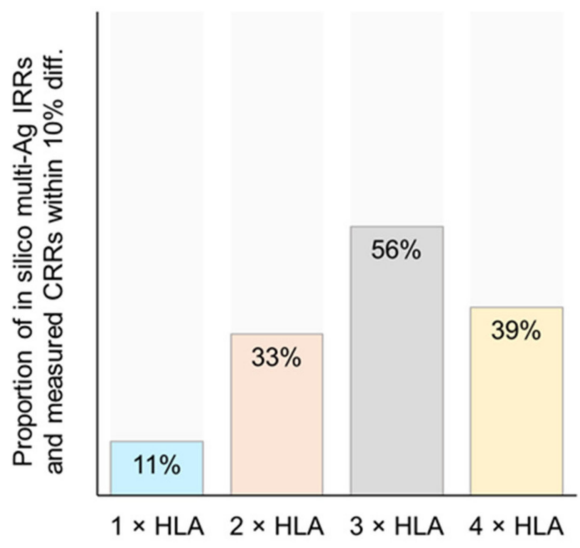

(e)

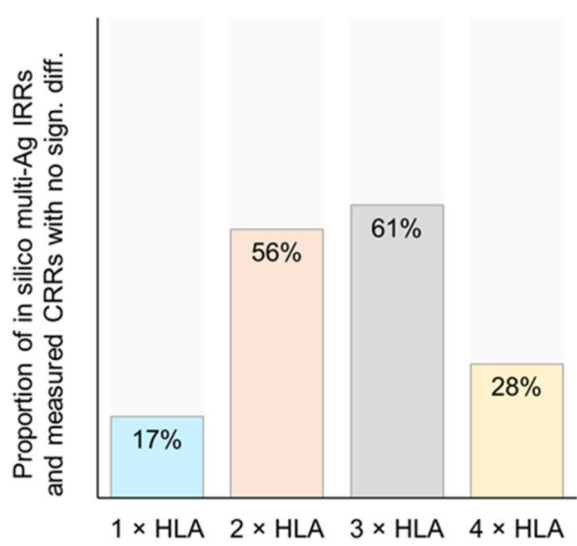

(f)

Figure 6. Correlation between CRRs measured by CTs and in silico multi-Ag IRRs. Analysis included 23 CTs with 16 vaccines, total of 18 data points. Prediction of multi-Ag IRRs is based on the frequency of subjects in the MP with at least two vaccine-specific epitopes originated from different protein antigens that are (a) restricted to $\geq 1$ autologous HLA class I allele $(r=0.2865, p=0.2491),(\mathbf{b})$ restricted to $\geq 2$ autologous HLA class I alleles $(r=0.5355, p=0.0220),(\mathbf{c})$ restricted to $\geq 3$ autologous HLA class I alleles $(r=0.6709, p=0.0023)$, (d) restricted to $\geq 4$ autologous HLA class I alleles $(r=0.7116, p=$ 0.0009). Orange dashed line: perpendicular trend line with $95 \%$ confidence interval band (95\% prediction interval band is shown by thicker dashed line). (e,f) Pairwise analysis of measured CRRs and predicted multi-Ag IRRs. Bars represent the proportion of the analyzed data pairs where difference was (e) within $10 \%$, (f) not significant $(p>0.05)$.

Eighteen data pairs of 23 CTs conducted with 16 vaccines were eligible for such analysis (Table A1). There was a good/strong correlation for each of the models where multiple HLA class I allele binding was required $(r=0.5355, r=0.6709$ and $r=0.7116$ for $2 \times$ HLA, $3 \times$ HLA, and $4 \times$ HLA, respectively), but not for single HLA allele binding epitopes $(r=0.2865, p=0.2491$ ) (Figure $6 \mathrm{~b}-\mathrm{d}$ ). A pairwise comparison of measured and predicted data showed (Figure 6 e) that $56 \%$ of the data pairs are within $10 \%$ difference and $61 \%$ differs non-significantly ( $p>0.05$, Figure $6 \mathrm{f}$ ) for epitopes restricted to $\geq 3$ autologous HLA class I alleles. All other HLA thresholds perform worse, especially the single HLA $(1 \times$ HLA) threshold where only $17 \%$ of data pairs matched. For the vaccines targeting multiple antigens no subgroup pairwise analysis of different vaccine types was performed, because 16/18 data points were peptide vaccines, with one plasmid DNA-based and one DC vaccine.

Of note, in the subgroup analysis of the 16 vaccines that target multiple antigens (analyzed above) in addition to the in silico multi-Ag IRRs, multi-epitope IRRs (Figure 7) also significantly correlated to CRR if $\geq 2$ HLA alleles were considered $(r(2 \times$ HLA $)=0.5253, r(3 \times$ HLA $)=$ $0.7463, r(4 \times$ HLA $)=0.7462)$. 


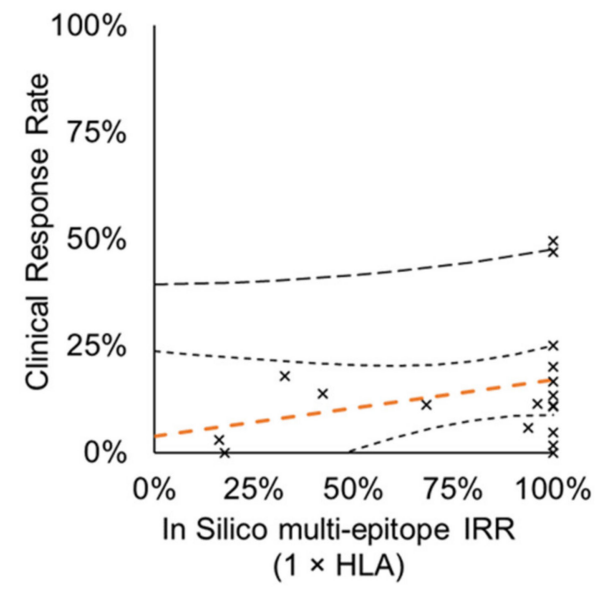

(a)

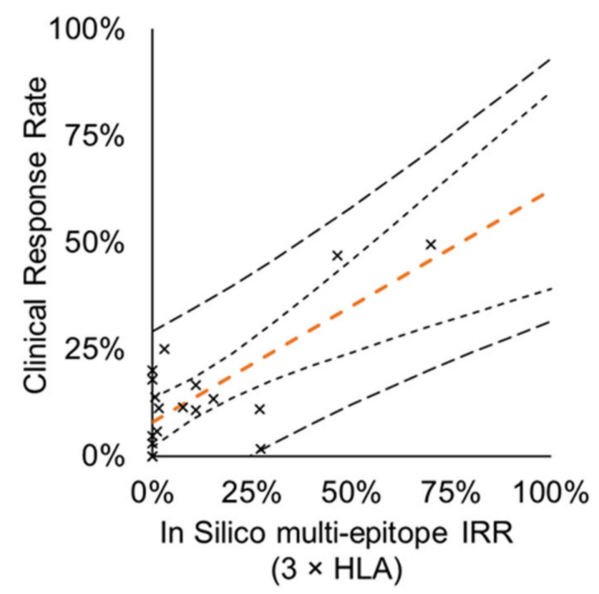

(c)

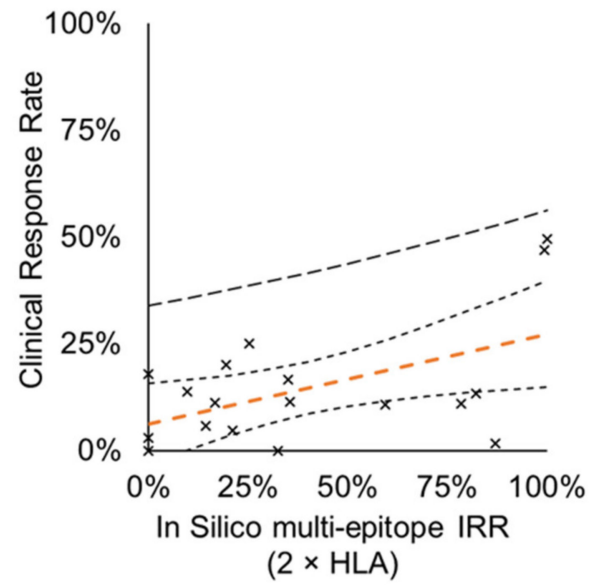

(b)

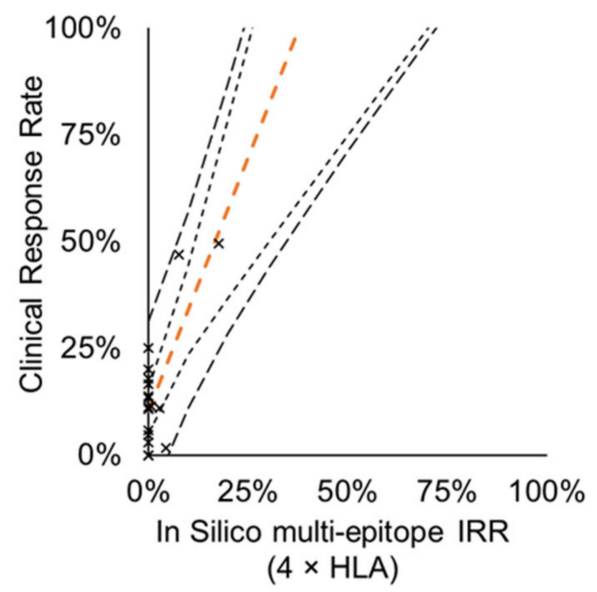

(d)

Figure 7. Correlation between CRRs measured by CTs and in silico multi-epitope IRRs of multiantigen-targeting vaccines. Analysis included 23 CTs with 16 vaccines, total of 18 data points. Prediction of multi-epitope IRRs is based on the frequency of subjects in the MP with at least two vaccine-specific epitope that are (a) restricted to $\geq 1$ autologous HLA class I allele $(r=0.2909, p=0.2415),(\mathbf{b})$ restricted to $\geq 2$ autologous HLA class I alleles $(r=0.5253, p=0.0252),(\mathbf{c})$ restricted to $\geq 3$ autologous HLA class I alleles $(r=0.7463, p=0.0004)$, (d) restricted to $\geq 4$ autologous HLA class I alleles $(r=0.7462, p=$ 0.0004). Orange dashed line: perpendicular trend line with $95 \%$ confidence interval band (95\% prediction interval band is shown by thicker dashed line).

These results suggest that polyclonality of the vaccine-induced $\mathrm{CD} 8^{+} \mathrm{T}$-cell responses is important to achieve tumor cell killing and thus tumor shrinkage.

\section{Discussion}

Despite the many controversial but unexplained data obtained for the immunogenicity of cancer vaccines, it is currently thought that HLA plays a major role in the development of the immune responses. Therefore, we hypothesized that all HLA alleles (HLA genotype) of a subject regulate immune responses not only some specific alleles. To investigate this concept an in silico cohort of real subjects was assembled and characterized as covering $97.4 \%$ of the global HLA alleles and major ethnicities. This cohort was used to retrospectively model the immunogenicity of therapeutic vaccines by predicting the proportion of subjects who are able to present vaccine-specific epitopes bound to their $\geq 1, \geq 2, \geq 3$ or $\geq 4$ autologous HLA alleles. This study shows that conventional prediction of T-cell responses based on a single HLA-restricted epitope highly overestimates in vitro measured IRR of vaccine CTs, and thus fails as trial enrichment strategy as well [16]. The study 
suggests that HLA allele binding is a required but potentially not sufficient criteria for in vitro measured T-cell responses.

It is also suggested here that the subjects' complete HLA genotype is a major determinant of vaccine responses. A positive relationship between the number of HLA alleles contributing to epitope binding and the IRR obtained in the studies is shown. We identified that $\geq 3$ autologous HLA allele binding epitopes link the subjects' HLA alleles with measured $\mathrm{CD}^{+} \mathrm{T}$-cell responses and correctly predict the immunogenicity outcome for the majority of studies. In this study the relationship between multiple autologous HLA allele-binding epitopes and T-cell responses was obtained on population (CT) level. In some earlier studies of our group where the patients' HLA genotype were available correlation was shown between measured T-cell responses and predicted epitopes that bind to $\geq 3$ autologous-HLA alleles on individual level (we call these epitopes personal epitopes, or PEPIs). In HLA-genotyped COVID-19 convalescent subjects our group reported significant correlation of measured T-cell responses and predicted SARS-CoV-2-specific PEPIs, while no association with single HLA-restricted epitopes was found [137]. Similar observations were made for HLA-genotyped patients with (pre)malignant cancers who were treated with a Synthetic Long Peptide Vaccine encoding HPV16, where we have found $90 \%$ agreement between the measured $\mathrm{CD}^{+} \mathrm{T}$-cell responses and the predicted PEPIs, but no correlation between single HLA-binding epitopes and T-cell responses [138]. Moreover, the magnitude of $\mathrm{CD} 8^{+} \mathrm{T}$-cell responses measured by ELISPOT assay was significantly higher for PEPIs compared to non-PEPIs [137]. These results indicate that conventional prediction of single HLA-restricted epitopes highly overestimates T-cell responses (high false positive rates) and could explain the high clinical failure rates of vaccines that are matched to only a single HLA allele of patients $[62,74,139]$, as well as the low specificity of predicted high affinity HLA class I binding neoepitopes [25,140,141].

The lack of correlation between individuals' immune responses and objective clinical responses is the major source of the skepticism associated with cancer vaccines $[1,2]$. These observations are further supported by the present analysis showing no correlation between IRR and CRR using the dataset of 42 CTs of 33 vaccines. Therefore, not surprisingly, there was also no correlation between the predicted IRR (with at least one vaccine-specific epitope) and reported CRR for these studies. However, when predicting multi-epitope responses or multi-antigenic responses (epitopes derived from at least two different antigens) for the vaccines targeting multiple tumor antigens, significant correlation was found for all HLA $\geq 2$ cut-off values but not with single HLA allele restricted epitopes. This result suggests that for IRRs reported with more stringent criteria (e.g., CD8 ${ }^{+} \mathrm{T}$-cell responses against at least two epitopes instead of one) correlations with CRR could be likely observed. Association between clinical benefit and immune response against multiple tumor targets were reported for few CTs. For the IMA901 renal cell carcinoma vaccine the disease control rate was associated with vaccine-induced immune responses in the subpopulation of multipeptide responders (T-cell responses to $\geq 2$ vaccine peptides) [142]. Multi-peptide response was also associated with longer overall survival [5]. In another multi-peptide vaccine against glioma the investigators reported a similar observation: patients with positive ELISPOT responses to two or more antigens were more likely to have objective radiological responses than those who responded to only a single peptide [47].

The fact that both IRR and CRR could be predicted by multiple HLA allele-restricted epitopes suggests T-cell involvement. This phenomenon is supported by the observation that the expression of individual classical HLA class I loci (HLA-A, -B and -C) has been found balanced within each human tissue with the highest level in immune cells [143]. Consequently, the same epitope can be naturally presented by more than one autologous class I HLA allele, suggesting that the A, B, and C alleles each contribute to the activation of T-cells, and consequently the more T-cells are elicited by the vaccine, the more IFN- $\gamma$ positive cells will be detected by the in vitro assays (i.e., ELISPOT). Moreover, multiple HLA allele restricted epitopes within a person may activate a broader repertoire of epitope specific T-cells with different T-cell receptor (TCR) clonotypes, thereby increasing the 
immunogenicity $[12-14,25,144]$. Furthermore, at the tumor side, the PEPIs might trigger more cytotoxic T-cell clones than epitopes restricted to a single HLA allele, as they could overcome the common tumor immune escape mechanism by HLA downregulation (thus less efficient epitope presentation) $[145,146]$. These results suggest that triggering multiple cytotoxic T-cell clones against (multiple) epitopes jointly presented by multiple HLA alleles on the surface of the tumor might be essential to achieve tumor shrinkage.

Our results confirm that there is a relationship between vaccine-induced immune responses and subsequent clinical responses, but only in a subgroup of subjects with a specific HLA genotype capable of presenting epitopes by their multiple HLA alleles. This is in good agreement with the recent finding that patients' HLA class I genotype (HLA heterozygosity) influences response to checkpoint inhibitor therapy presumably due to efficient HLA presentation of tumor antigens triggering efficient $C D 8^{+} T-c e l l$ responses [147].

Objective tumor responses may depend on multiple variables (e.g., true expression of target antigens on the heterogeneous tumor) and definitely one of them is the generation of multi-targeted T-cell responses. Therefore, the design of therapeutic cancer vaccines should focus first of all on ensuring robust immune responses against the encoded (multiple) tumor targets in each subject. Preclinical animal models are indisputably important for the mapping and understanding of the mechanism of action of immunotherapeutics, however it is well-known that preclinical immunogenicity and efficacy does not correlate well with human results $[148,149]$. Therefore, a new in silico tool that could accurately predict the immunogenicity of therapeutic vaccines could bring a revolution to the development of cancer vaccines. Such a model should rely on subjects with complete HLA genotype rather than on single alleles. This could be used also for in silico epitope mapping in the design of the vaccines, to select the epitopes that are predicted to be immunogenic in the majority of subjects or ethnic populations.

This study has several limitations. The basic limitation is that the cohort used in this study is not the same as the CT populations. Although the HLA allele coverage compared to the CIWD database was shown to be similar, HLA-genotype of the individuals cannot be confirmed. Since HLA alleles have a major role in tumor surveillance, many groups explored and found associations of certain HLA alleles or haplotypes with cancers, including melanoma [150], breast cancer [151], colorectal cancer [152], head \& neck cancer [153], cervical cancer [154], and ovarian cancer [155]. These studies revealed the increase or decrease in the frequency of the specific alleles, notably most of these associations were identified with HLA class II alleles. In a recent publication, Marty and co-workers reported their finding, that HLA class I genotype of cancer subjects shape their tumors' mutational profile by eliminating through immunological reactions those neoepitopes that are highly presented by the HLAs [156]. These results however, support our finding. The lack of a reference dataset for frequent HLA allele combinations or HLA genotypes limits the unambiguous demonstration of representativeness for our MP. The model may be fine-tuned by the use of in silico populations assembled from HLA-genotyped subjects having the target disease, which could result in a more accurate estimation of clinical outcomes. Another limitation is that since the model is based on the genetic capability of a person to present epitopes and mount immune responses, it was not possible to address or incorporate the contribution of vaccine antigen type, formulation [157-160], route of administration [91], or dosing and schedule. A marginal limitation of the study is the variability of the immunoassays used for the determination of immune responders, which not only applies to the use of different assays but also varying thresholds or criteria for positivity. There is no gold standard or approved in vitro diagnostic device to measure vaccine induced T-cell responses, and standardization/validation of bioassays is often problematic even within the same laboratory [161-163]. This issue may contribute to the poor reproducibility of IRR across CTs. This was apparent in case of the p53 SLP70-248 vaccine CTs, where in one study none of the ten enrolled subjects had immune response but in other studies with comparable sample sizes the IRR was $88 \%$ and $100 \%$ (Table A1) [82-84]. If the true IRR was larger than $88 \%$, then the probability of not detecting any immune response in ten 
subjects is extremely low $\left(<1.38 \times 10^{-9}\right)$. Of course, the small sample size of the CTs may also contribute to such issues. The other major limitation of the study is that the effect of previous treatments is not taken into consideration, however it may have huge impact, especially on the clinical response, when modulating tumor microenvironment [1,164-167]. When evaluating the correlations with clinical responses, we have to note the lack of CRR results published above $50 \%$, which is a serious limitation of this analysis, and we think that the inclusion of successful trials (CRR > 50\%) in our analysis would greatly improve the correlations.

\section{Conclusions}

This study shows that our in silico model together with the promiscuous autologous HLA allele binding epitope concept is able to estimate both the IRR and CRR of CTs. Moreover, to the best of our knowledge, for the first time in the literature correlation between IRR and CRR was found across multiple cancer vaccine studies. In all analyzed aspects predicted multiple HLA allele-binding epitopes outperformed the conventional single HLA-binding epitopes, which is potentially thought-provoking. The ability to predict the clinical outcome of therapeutic vaccine trials could expedite vaccine development by enabling the most immunologically powerful vaccine candidates to be selected for clinical testing. This could increase the likelihood of clinical success and reduce the need for large studies. Consequently, the clinical development time and cost of therapeutic vaccines could be reduced substantially.

\section{Patents}

The Authors filed patent application (WO2018/158456) resulting from the work reported.

Supplementary Materials: The following are available online at https: / www.mdpi.com/article/ 10.3390 /cells10113048/s1, Table S1. Coverage of the HLA alleles in the MP, Table S2. Receiver Operating Characteristic (ROC) curve AUC values of the in silico IRR predictions, Figure S1. Pairwise Chi square analysis of measured and predicted IRRs, grouped by vaccine types, Figure S2. Pairwise Chi square analysis of measured CRRs and predicted multi-epitope IRRs, grouped by vaccine types.

Author Contributions: Conceptualization, E.R.T. and O.L.; methodology and formal analysis, O.L., L.M., J.T. and I.M.; software, J.T.; data curation, J.T., O.L., E.S., Z.C., K.P. and M.M.; writing-original draft preparation, O.L.; writing-review and editing, E.R.T.; visualization, O.L., L.M. and J.T. All authors have read and agreed to the published version of the manuscript.

Funding: This research received no external funding.

Institutional Review Board Statement: In this study clinical data was collected from peer-reviewed publications. Ethical statement for the clinical trials is provided in each referenced publication.

Informed Consent Statement: Informed consent was obtained from all subjects involved in the referenced studies.

Data Availability Statement: The data that support the findings of this study are available on request from the corresponding author.

Conflicts of Interest: All authors hold shares of Treos Bio Ltd.

\section{Appendix A}

The following tables are in an appendix excel file: 
Table A1. Immune- and clinical response rates reported in the referenced studies. When the same vaccine was used in multiple trials the response rates were combined.

\begin{tabular}{|c|c|c|c|c|c|c|c|c|c|c|c|}
\hline \multirow[b]{2}{*}{ Vaccine } & \multirow[b]{2}{*}{ IRR } & \multirow[b]{2}{*}{ CRR } & \multirow[b]{2}{*}{$\begin{array}{c}\text { Combined } \\
\text { IRR }\end{array}$} & \multirow[b]{2}{*}{$\begin{array}{c}\text { Combined } \\
\text { CRR }\end{array}$} & \multirow[b]{2}{*}{ Ref. } & \multicolumn{6}{|c|}{ Included in Analysis (X) } \\
\hline & & & & & & $\begin{array}{c}\text { IRR-CRR } \\
\text { Correlations }\end{array}$ & $\begin{array}{c}\text { IRR in CTs } \\
\text { with/without } \\
\text { HLA } \\
\text { Preselection }\end{array}$ & $\begin{array}{l}\text { High Binding, } \\
\text { Low Binding } \\
\text { Epitope } \\
\text { Vaccines }\end{array}$ & $\begin{array}{c}\text { Measured } \\
\text { and In Silico } \\
\text { IRR } \\
\text { Correlations }\end{array}$ & $\begin{array}{c}\text { Measured } \\
\text { CRR-In Silico } \\
\text { IRR } \\
\text { Correlations } \\
\end{array}$ & $\begin{array}{c}\text { MultiAg } \\
\text { Correlations }\end{array}$ \\
\hline 9-peptide breast cancer vaccine & $36 \%$ & - & $36 \%$ & - & [37] & & $x$ & & $x$ & & \\
\hline AFP-derived peptides & $33 \%$ & $7 \%$ & $33 \%$ & $7 \%$ & [38] & $x$ & $x$ & & $x$ & $x$ & \\
\hline Antigen-pulsed DC vaccine & $38 \%$ & - & $38 \%$ & - & [39] & & $x$ & & $x$ & & \\
\hline CD34 DC vaccine & $44 \%$ & - & $44 \%$ & - & [40] & & $x$ & & $x$ & & \\
\hline DCCP peptide vaccine & $56 \%$ & $11 \%$ & $56 \%$ & $11 \%$ & [23] & $x$ & $x$ & & $x$ & $x$ & $x$ \\
\hline DPX0907 peptide vaccine & $61 \%$ & - & $61 \%$ & - & {$[43,44]$} & & $x$ & & $x$ & & \\
\hline Elenagen pDNA vaccine & - & $0 \%$ & - & $0 \%$ & [45] & & & & & $x$ & \\
\hline EMD640744 peptide vaccine & $63 \%$ & - & $63 \%$ & - & [22] & & $x$ & & $x$ & & \\
\hline Five-peptide cancer vaccine & - & $11 \%$ & - & $11 \%$ & [46] & & & & & $x$ & $x$ \\
\hline \multirow{2}{*}{ GAA peptides vaccine } & $100 \%$ & $29 \%$ & \multirow{2}{*}{$71 \%$} & \multirow{2}{*}{$20 \%$} & {$[47]$} & \multirow{2}{*}{$x$} & \multirow[t]{2}{*}{$\mathrm{x}$} & $x$ & \multirow{2}{*}{$\mathrm{x}$} & \multirow{2}{*}{$\mathrm{x}$} & \multirow{2}{*}{$\mathrm{x}$} \\
\hline & $55 \%$ & $15 \%$ & & & [48] & & & & & & \\
\hline \multirow{2}{*}{ GL-0817 (MAGE-A3 Trojan) } & $0 \%$ & $0 \%$ & \multirow{2}{*}{$33 \%$} & \multirow{2}{*}{$0 \%$} & [49] & $\mathrm{x}$ & $x$ & & \multirow{2}{*}{$x$} & $\mathrm{x}$ & \\
\hline & $57 \%$ & - & & & [51] & & $x$ & & & & \\
\hline \multirow{2}{*}{ Glypican-3 peptide vaccine (A24) } & $33 \%$ & $33 \%$ & \multirow{2}{*}{$64 \%$} & \multirow{2}{*}{$18 \%$} & & \multirow{2}{*}{$x$} & \multirow{2}{*}{$x$} & $x$ & \multirow{2}{*}{$x$} & & . \\
\hline & $100 \%$ & $0 \%$ & & & {$[52,53]$} & & & $x$ & & & \\
\hline \multirow{2}{*}{ Glypican-3 peptide vaccine (A02) } & $67 \%$ & $0 \%$ & \multirow{2}{*}{$53 \%$} & $38 \%$ & & $x$ & $x$ & $x$ & $x$ & & \\
\hline & $45 \%$ & $60 \%$ & & & & & & $x$ & & & \\
\hline GVX301 peptide vaccine & $64 \%$ & $0 \%$ & $64 \%$ & $0 \%$ & [54] & $x$ & $x$ & & $x$ & $x$ & \\
\hline HER1 vaccine & $42 \%$ & & $42 \%$ & - & [55] & & $x$ & & $x$ & & \\
\hline HER2 B cell vaccine & & & - & $6 \%$ & [56] & & & & & $x$ & \\
\hline Her2/neu peptide vaccine (p369) & $62 \%$ & & & - & & & & & $x$ & & \\
\hline Her2/neu peptide vaccine (p688) & $31 \%$ & & $62 \%$ & - & [57] & & $x$ & $x$ & $x$ & & \\
\hline Her2/neu peptide vaccine (p971) & $54 \%$ & & & - & & & & $x$ & $x$ & & \\
\hline HIVIS (HIV gag) & $80 \%$ & & $80 \%$ & - & [58] & & $x$ & & $x$ & & \\
\hline HIVIS (HIV RT) & $50 \%$ & & $50 \%$ & - & [58] & & $x$ & & $x$ & & \\
\hline
\end{tabular}


Table A1. Cont.

\begin{tabular}{|c|c|c|c|c|c|c|c|c|c|c|c|}
\hline \multirow[b]{2}{*}{ Vaccine } & \multirow[b]{2}{*}{ IRR } & \multirow[b]{2}{*}{ CRR } & \multirow[b]{2}{*}{$\begin{array}{l}\text { Combined } \\
\text { IRR }\end{array}$} & \multirow[b]{2}{*}{$\begin{array}{c}\text { Combined } \\
\text { CRR }\end{array}$} & \multirow[b]{2}{*}{ Ref. } & \multicolumn{6}{|c|}{ Included in Analysis (X) } \\
\hline & & & & & & $\begin{array}{l}\text { IRR-CRR } \\
\text { Correlations }\end{array}$ & $\begin{array}{c}\text { IRR in CTs } \\
\text { with/without } \\
\text { HLA } \\
\text { Preselection }\end{array}$ & $\begin{array}{l}\text { High Binding, } \\
\text { Low Binding } \\
\text { Epitope } \\
\text { Vaccines }\end{array}$ & $\begin{array}{c}\text { Measured } \\
\text { and In Silico } \\
\text { IRR } \\
\text { Correlations }\end{array}$ & $\begin{array}{c}\text { Measured } \\
\text { CRR-In Silico } \\
\text { IRR } \\
\text { Correlations } \\
\end{array}$ & $\begin{array}{c}\text { MultiAg } \\
\text { Correlations }\end{array}$ \\
\hline \multirow[t]{2}{*}{ HPV-SLP } & $100 \%$ & $60 \%$ & $87 \%$ & \multirow[t]{2}{*}{$47 \%$} & {$[60]$} & $x$ & $x$ & & $x$ & \multirow{2}{*}{$x$} & \multirow{2}{*}{$x$} \\
\hline & - & $33 \%$ & & & [61] & & & & & & \\
\hline ICT107 & $33 \%$ & & $33 \%$ & - & [62] & & $x$ & & $x$ & & \\
\hline IDOlong peptide vaccine & $10 \%$ & $10 \%$ & $10 \%$ & $10 \%$ & {$[64]$} & $x$ & $x$ & & $x$ & $x$ & \\
\hline \multirow{2}{*}{ IMA901 } & $64 \%$ & - & \multirow{2}{*}{$67 \%$} & \multirow{2}{*}{-} & \multirow{2}{*}{ [5] } & & $x$ & & \multirow{2}{*}{$x$} & 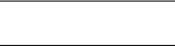 & \\
\hline & $74 \%$ & - & & & & & $x$ & & & & \\
\hline \multirow{3}{*}{ IMA950 } & $63 \%$ & $0 \%$ & \multirow{3}{*}{$81 \%$} & \multirow{2}{*}{$2 \%$} & [65] & \multirow{3}{*}{$x$} & $x$ & & \multirow{3}{*}{$x$} & \multirow{2}{*}{$x$} & \multirow{2}{*}{$x$} \\
\hline & $81 \%$ & $3 \%$ & & & {$[66]$} & & $x$ & & & & \\
\hline & $90 \%$ & - & & & [67] & & $x$ & & & & \\
\hline ImMucin & $100 \%$ & $47 \%$ & $96 \%$ & $47 \%$ & {$[68,69]$} & $x$ & $x$ & & $x$ & $x$ & \\
\hline IMP321/LAG-3Ig + peptides vaccine & $40 \%$ & - & $40 \%$ & - & {$[70]$} & & $x$ & $x$ & $x$ & & \\
\hline KIF20A-66 peptide vaccine & $70 \%$ & $26 \%$ & $70 \%$ & $26 \%$ & [72] & $x$ & $x$ & $x$ & $x$ & $x$ & \\
\hline KRM-20 vaccine & $40 \%$ & $13 \%$ & $40 \%$ & $13 \%$ & [73] & $x$ & $x$ & & $x$ & $x$ & $x$ \\
\hline MART-1 Peptide Vaccine & $15 \%$ & - & $15 \%$ & - & [74] & & $x$ & $x$ & $x$ & & \\
\hline Melanoma peptide vaccine & $52 \%$ & $12 \%$ & $52 \%$ & $12 \%$ & [75] & $x$ & $x$ & & $x$ & $x$ & $x$ \\
\hline MELITAC 12.1 & $49 \%$ & - & $49 \%$ & - & {$[24]$} & & $x$ & & $x$ & & \\
\hline Multiepitope peptide vaccine & $89 \%$ & $0 \%$ & $89 \%$ & $0 \%$ & [76] & $x$ & $x$ & $x$ & $x$ & $x$ & $x$ \\
\hline NY-ESO-1 OLP & $82 \%$ & - & $82 \%$ & $0 \%$ & $\begin{array}{l}{[77]} \\
{[78]}\end{array}$ & & $x$ & & $x$ & $x$ & \\
\hline NY-ESO-1f & $90 \%$ & $0 \%$ & $90 \%$ & $0 \%$ & [79] & $x$ & $x$ & & $x$ & $x$ & \\
\hline OCV-C02 vaccine & $63 \%$ & $0 \%$ & $63 \%$ & $0 \%$ & {$[80]$} & $x$ & $x$ & & $x$ & $x$ & $x$ \\
\hline p53 SLP70-235 & $21 \%$ & - & $21 \%$ & - & [81] & & $x$ & & $x$ & & \\
\hline \multirow{3}{*}{ p53 SLP70-248 } & $0 \%$ & - & \multirow{3}{*}{$69 \%$} & & [82] & & $x$ & & & & \\
\hline & $88 \%$ & $0 \%$ & & $0 \%$ & [83] & $x$ & $x$ & & $x$ & $x$ & \\
\hline & $100 \%$ & $0 \%$ & & & [84] & & $x$ & & & & \\
\hline p53MVA vaccine & $55 \%$ & $9 \%$ & $55 \%$ & $9 \%$ & [85] & $x$ & $x$ & & $x$ & $x$ & \\
\hline PepCan & $65 \%$ & $52 \%$ & $65 \%$ & $52 \%$ & [86] & $x$ & $x$ & & $x$ & $x$ & \\
\hline
\end{tabular}


Table A1. Cont.

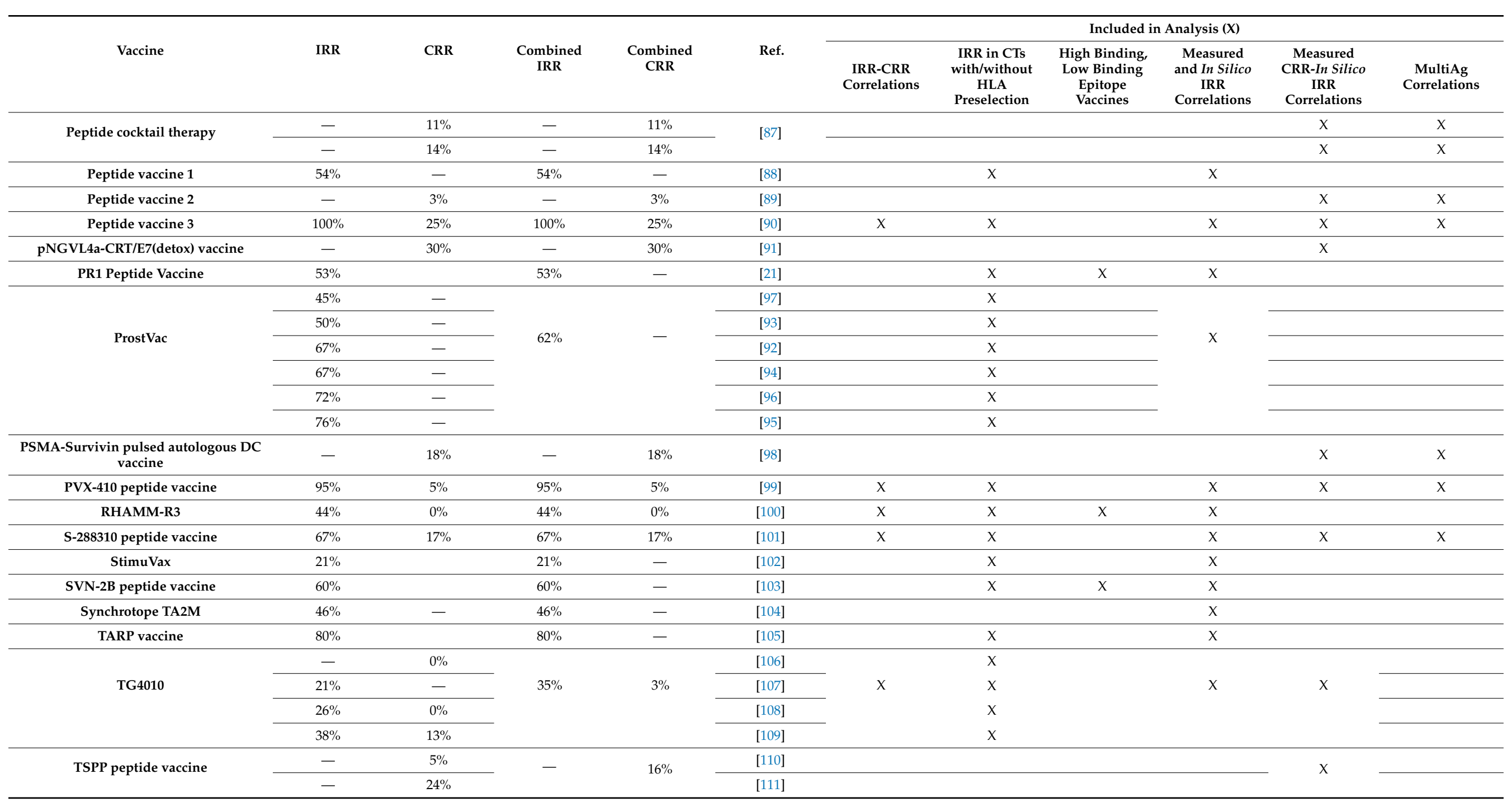


Table A1. Cont.

\begin{tabular}{|c|c|c|c|c|c|c|c|c|c|c|c|}
\hline \multirow[b]{2}{*}{ Vaccine } & \multirow[b]{2}{*}{ IRR } & \multirow[b]{2}{*}{ CRR } & \multirow[b]{2}{*}{$\begin{array}{c}\text { Combined } \\
\text { IRR }\end{array}$} & \multirow[b]{2}{*}{$\begin{array}{c}\text { Combined } \\
\text { CRR }\end{array}$} & \multirow[b]{2}{*}{ Ref. } & \multicolumn{6}{|c|}{ Included in Analysis (X) } \\
\hline & & & & & & $\begin{array}{l}\text { IRR-CRR } \\
\text { Correlations }\end{array}$ & $\begin{array}{c}\text { IRR in CTs } \\
\text { with/without } \\
\text { HLA } \\
\text { Preselection } \\
\end{array}$ & $\begin{array}{c}\text { High Binding, } \\
\text { Low Binding } \\
\text { Epitope } \\
\text { Vaccines } \\
\end{array}$ & $\begin{array}{c}\text { Measured } \\
\text { and In Silico } \\
\text { IRR } \\
\text { Correlations }\end{array}$ & $\begin{array}{c}\text { Measured } \\
\text { CRR-In Silico } \\
\text { IRR } \\
\text { Correlations } \\
\end{array}$ & $\begin{array}{l}\text { MultiAg } \\
\text { Correlations }\end{array}$ \\
\hline VGX-3100 & - & $50 \%$ & $78 \%$ & $50 \%$ & [113] & $\mathrm{x}$ & & & $x$ & $x$ & $\mathrm{x}$ \\
\hline \multirow{4}{*}{$V x-001$} & $51 \%$ & - & \multirow{4}{*}{$59 \%$} & & [114] & \multirow{4}{*}{$x$} & $x$ & & & & \\
\hline & $58 \%$ & $4 \%$ & & \multirow{3}{*}{$4 \%$} & [115] & & $x$ & & \multirow{3}{*}{$\mathrm{x}$} & \multirow{3}{*}{$\mathrm{x}$} & \\
\hline & $66 \%$ & $7 \%$ & & & [117] & & $x$ & & & & \\
\hline & $71 \%$ & $0 \%$ & & & [116] & & $x$ & & & & \\
\hline \multirow{3}{*}{ WT1 vaccine (1) } & $64 \%$ & $0 \%$ & \multirow{3}{*}{$59 \%$} & \multirow{3}{*}{$4 \%$} & [118] & \multirow{2}{*}{$\mathrm{x}$} & $x$ & \multirow{3}{*}{$x$} & \multirow{3}{*}{$\mathrm{x}$} & \multirow{3}{*}{$x$} & \\
\hline & $40 \%$ & $10 \%$ & & & [119] & & $x$ & & & & \\
\hline & $86 \%$ & $0 \%$ & & & [120] & $x$ & $x$ & & & & \\
\hline WT1 peptide vaccine & $72 \%$ & $6 \%$ & $72 \%$ & $6 \%$ & [121] & $x$ & $x$ & $x$ & $x$ & & \\
\hline WT1 peptides & $100 \%$ & $14 \%$ & $100 \%$ & $14 \%$ & [122] & $x$ & $x$ & & $x$ & $x$ & \\
\hline WT1 vaccine (2) & $83 \%$ & - & $83 \%$ & - & [123] & & $x$ & & $x$ & & \\
\hline
\end{tabular}


Table A2. HLA alleles of the model population and their frequency according to the Catalog of common, intermediate and well-documented HLA alleles (CIWD) [129].

\begin{tabular}{|c|c|}
\hline HLA Allele & Frequency in CIWD \\
\hline HLA-A*02:01 & 0.24065 \\
\hline HLA-A*01:01 & 0.13343 \\
\hline HLA-C*07:01 & 0.11948 \\
\hline HLA-A*03:01 & 0.11852 \\
\hline HLA-C*07:02 & 0.11093 \\
\hline HLA-C ${ }^{*} 04: 01$ & 0.11062 \\
\hline HLA-B*07:02 & 0.10205 \\
\hline HLA-A*24:02 & 0.08948 \\
\hline HLA-C*06:02 & 0.08771 \\
\hline HLA-B*08:01 & 0.08462 \\
\hline HLA-B*44:02 & 0.06295 \\
\hline HLA-A*11:01 & 0.06098 \\
\hline HLA-C*03:04 & 0.06076 \\
\hline HLA-C*05:01 & 0.05597 \\
\hline HLA-C ${ }^{*} 12: 03$ & 0.05491 \\
\hline HLA-B*51:01 & 0.05432 \\
\hline HLA-B*35:01 & 0.05270 \\
\hline HLA-B*15:01 & 0.05000 \\
\hline HLA-B*18:01 & 0.04534 \\
\hline HLA-C*02:02 & 0.04281 \\
\hline HLA-B*44:03 & 0.04280 \\
\hline HLA-C*03:03 & 0.04237 \\
\hline HLA-B*40:01 & 0.03957 \\
\hline HLA-C*01:02 & 0.03512 \\
\hline HLA-A*26:01 & 0.03352 \\
\hline HLA-A*68:01 & 0.03338 \\
\hline HLA-A*32:01 & 0.03200 \\
\hline HLA-B*57:01 & 0.03134 \\
\hline HLA-B*27:05 & 0.02952 \\
\hline HLA-B*13:02 & 0.02899 \\
\hline HLA-C*15:02 & 0.02573 \\
\hline HLA-C*08:02 & 0.02483 \\
\hline HLA-A*31:01 & 0.02462 \\
\hline HLA-B*35:03 & 0.02344 \\
\hline HLA-C*16:01 & 0.02241 \\
\hline HLA-B*38:01 & 0.02218 \\
\hline HLA-A*29:02 & 0.02166 \\
\hline HLA-A*25:01 & 0.02124 \\
\hline HLA-A*23:01 & 0.02096 \\
\hline
\end{tabular}


Table A2. Cont.

\begin{tabular}{|c|c|}
\hline HLA Allele & Frequency in CIWD \\
\hline HLA-B*14:02 & 0.02042 \\
\hline HLA-C*07:04 & 0.01709 \\
\hline HLA-B*52:01 & 0.01659 \\
\hline HLA-A*30:01 & 0.01589 \\
\hline HLA-B*40:02 & 0.01534 \\
\hline HLA-C ${ }^{*} 12: 02$ & 0.01526 \\
\hline HLA-B*49:01 & 0.01498 \\
\hline HLA-B*55:01 & 0.01438 \\
\hline HLA-C ${ }^{*} 14: 02$ & 0.01383 \\
\hline HLA-A*33:03 & 0.01360 \\
\hline HLA-B*37:01 & 0.01334 \\
\hline HLA-C ${ }^{*} 17: 01$ & 0.01273 \\
\hline HLA-B*58:01 & 0.01224 \\
\hline HLA-B*50:01 & 0.01189 \\
\hline HLA-B*39:01 & 0.01158 \\
\hline HLA-B*35:02 & 0.01027 \\
\hline HLA-A*02:05 & 0.00878 \\
\hline HLA-A*30:02 & 0.00838 \\
\hline HLA-A*68:02 & 0.00834 \\
\hline HLA-B*56:01 & 0.00784 \\
\hline HLA-C*03:02 & 0.00779 \\
\hline HLA-A*33:01 & 0.00749 \\
\hline HLA-B*40:06 & 0.00719 \\
\hline HLA-B*53:01 & 0.00696 \\
\hline HLA-B*45:01 & 0.00604 \\
\hline HLA-B*07:05 & 0.00593 \\
\hline HLA-B*41:01 & 0.00592 \\
\hline HLA-B*41:02 & 0.00579 \\
\hline HLA-B*14:01 & 0.00578 \\
\hline HLA-A*02:06 & 0.00569 \\
\hline HLA-C ${ }^{*} 15: 05$ & 0.00537 \\
\hline HLA-C*08:01 & 0.00515 \\
\hline HLA-B*39:06 & 0.00514 \\
\hline HLA-A*02:11 & 0.00463 \\
\hline HLA-A*66:01 & 0.00463 \\
\hline HLA-A*29:01 & 0.00413 \\
\hline HLA-A*03:02 & 0.00368 \\
\hline HLA-B*15:03 & 0.00337 \\
\hline HLA-B*15:18 & 0.00281 \\
\hline HLA-C*02:10 & 0.00275 \\
\hline
\end{tabular}


Table A2. Cont.

\begin{tabular}{|c|c|}
\hline HLA Allele & Frequency in CIWD \\
\hline HLA-B*15:02 & 0.00261 \\
\hline HLA-A*02:02 & 0.00239 \\
\hline HLA-A*24:03 & 0.00236 \\
\hline HLA-B*48:01 & 0.00229 \\
\hline HLA-B*13:01 & 0.00219 \\
\hline HLA-B*46:01 & 0.00215 \\
\hline HLA-C ${ }^{*} 16: 04$ & 0.00208 \\
\hline HLA-A*74:01 & 0.00200 \\
\hline HLA-B*57:03 & 0.00193 \\
\hline HLA-B*42:01 & 0.00193 \\
\hline HLA-A*02:07 & 0.00183 \\
\hline HLA-A*30:04 & 0.00183 \\
\hline HLA-A*02:03 & 0.00174 \\
\hline HLA-B*38:02 & 0.00171 \\
\hline HLA-A*34:02 & 0.00162 \\
\hline HLA-B*39:05 & 0.00159 \\
\hline HLA-B*15:10 & 0.00145 \\
\hline HLA-C ${ }^{*} 18: 01$ & 0.00136 \\
\hline HLA-B*58:02 & 0.00136 \\
\hline HLA-A*36:01 & 0.00097 \\
\hline HLA-B*15:16 & 0.00095 \\
\hline HLA-A*68:03 & 0.00084 \\
\hline HLA-B*54:01 & 0.00075 \\
\hline HLA-C*08:03 & 0.00073 \\
\hline HLA-B*35:17 & 0.00073 \\
\hline HLA-B*81:01 & 0.00067 \\
\hline HLA-C*14:03 & 0.00067 \\
\hline HLA-A*11:02 & 0.00056 \\
\hline HLA-B*39:24 & 0.00052 \\
\hline HLA-B*15:07 & 0.00049 \\
\hline HLA-A*80:01 & 0.00045 \\
\hline HLA-B*57:02 & 0.00045 \\
\hline HLA-B*35:43 & 0.00044 \\
\hline HLA-B*39:10 & 0.00043 \\
\hline HLA-B*42:02 & 0.00041 \\
\hline HLA-B*27:04 & 0.00041 \\
\hline HLA-C*08:04 & 0.00036 \\
\hline HLA-B*78:01 & 0.00033 \\
\hline HLA-C ${ }^{*} 12: 04$ & 0.00030 \\
\hline HLA-B*39:09 & 0.00029 \\
\hline
\end{tabular}


Table A2. Cont.

\begin{tabular}{|c|c|}
\hline HLA Allele & Frequency in CIWD \\
\hline HLA-A*66:02 & 0.00028 \\
\hline HLA-A*02:22 & 0.00025 \\
\hline HLA-B*15:04 & 0.00021 \\
\hline HLA-B*40:04 & 0.00021 \\
\hline HLA-B*15:11 & 0.00020 \\
\hline HLA-B*67:01 & 0.00014 \\
\hline HLA-B*35:20 & 0.00013 \\
\hline HLA-A*11:03 & 0.00013 \\
\hline HLA-C*04:04 & 0.00012 \\
\hline HLA-A*29:10 & 0.00012 \\
\hline HLA-B*14:03 & 0.00010 \\
\hline HLA-A*26:02 & 0.00009 \\
\hline HLA-B*59:01 & 0.00009 \\
\hline HLA-C*01:03 & 0.00008 \\
\hline HLA-B*40:11 & 0.00007 \\
\hline HLA-A*66:03 & 0.00007 \\
\hline HLA-A*26:03 & 0.00006 \\
\hline HLA-A*02:24 & 0.00006 \\
\hline HLA-B*39:13 & 0.00004 \\
\hline HLA-C*06:06 & 0.00003 \\
\hline HLA-A*02:14 & 0.00002 \\
\hline HLA-A*43:01 & 0.00002 \\
\hline HLA-A*36:03 & 0.00001 \\
\hline HLA-B*40:64 & 0.00001 \\
\hline HLA-A*02:87 & 0.00000 \\
\hline HLA-C ${ }^{*} 05: 11$ & 0.00000 \\
\hline HLA-A*03:17 & 0.00000 \\
\hline HLA-A*24:04 & 0.00000 \\
\hline HLA-B*13:03 & 0.00000 \\
\hline HLA-C*06:11 & 0.00000 \\
\hline HLA-A*24:24 & 0.00000 \\
\hline HLA-B*41:04 & 0.00000 \\
\hline HLA-B*49:02 & 0.00000 \\
\hline
\end{tabular}

\section{References}

1. Perez-Diez, A.; Spiess, P.J.; Restifo, N.P.; Matzinger, P.; Marincola, F.M. Intensity of the Vaccine-Elicited Immune Response Determines Tumor Clearance. J. Immunol. 2002, 168, 338-347. [CrossRef]

2. $\quad$ Lee, K.-H.; Wang, E.; Nielsen, M.-B.; Wunderlich, J.; Migueles, S.; Connors, M.; Steinberg, S.M.; Rosenberg, S.A.; Marincola, F.M. Increased Vaccine-Specific T Cell Frequency After Peptide-Based Vaccination Correlates with Increased Susceptibility to In Vitro Stimulation But Does Not Lead to Tumor Regression. J. Immunol. 1999, 163, 6292-6300.

3. Disis, M.L. Immunologic biomarkers as correlates of clinical response to cancer immunotherapy. Cancer Immunol. Immunother. 2011, 60, 433-442. [CrossRef] 
4. Wheeler, C.J.; Black, K.L.; Liu, G.; Mazer, M.; Zhang, X.X.; Pepkowitz, S.; Goldfinger, D.; Ng, H.; Irvin, D.; Yu, J.S. Vaccination elicits correlated immune and clinical responses in glioblastoma multiforme patients. Cancer Res. 2008, 68, 5955-5964. [CrossRef] [PubMed]

5. Walter, S.; Weinschenk, T.; Stenzl, A.; Zdrojowy, R.; Pluzanska, A.; Szczylik, C.; Staehler, M.; Brugger, W.; Dietrich, P.Y.; Mendrzyk, R.; et al. Multipeptide immune response to cancer vaccine IMA901 after single-dose cyclophosphamide associates with longer patient survival. Nat. Med. 2012, 18, 1254-1261. [CrossRef] [PubMed]

6. Schneble, E.J.; Berry, J.S.; Trappey, F.A.; Clifton, G.T.; Ponniah, S.; Mittendorf, E.; Peoples, G.E. The HER2 peptide nelipepimut-S (E75) vaccine $\left(\mathrm{NeuVax}^{\mathrm{TM}}\right)$ in breast cancer patients at risk for recurrence: Correlation of immunologic data with clinical response. Immunotherapy 2014, 6, 519-531. [CrossRef]

7. Zinkernagel, R.M.; Doherty, P.C. Restriction of in vitro T cell-mediated cytotoxicity in lymphocytic choriomeningitis within a syngeneic or semiallogeneic system. Nature 1974, 248, 701-702. [CrossRef] [PubMed]

8. Zinkernagel, R.M.; Doherty, P.C. Immunological surveillance against altered self components by sensitised T lymphocytes in lymphocytic choriomeningitis. Nature 1974, 251, 547-548. [CrossRef] [PubMed]

9. Bjorkman, P.J.; Saper, M.A.; Samraoui, B.; Bennett, W.S.; Strominger, J.L.; Wiley, D.C. Structure of the human class I histocompatibility antigen, HLA-A2. Nature 1987, 329, 506-512. [CrossRef]

10. Bjorkman, P.J.; Saper, M.A.; Samraoui, B.; Bennett, W.S.; Strominger, J.L.; Wiley, D.C. The foreign antigen binding site and T cell recognition regions of class I histocompatibility antigens. Nature 1987, 329, 512-518. [CrossRef]

11. Fritsch, E.F.; Rajasagi, M.; Ott, P.A.; Brusic, V.; Hacohen, N.; Wu, C.J. HLA-binding properties of tumor neoepitopes in humans. Cancer Immunol. Res. 2014, 2, 522-529. [CrossRef] [PubMed]

12. Song, I.; Gil, A.; Mishra, R.; Ghersi, D.; Selin, L.K.; Stern, L.J. Broad TCR repertoire and diverse structural solutions for recognition of an immunodominant CD8(+) T cell epitope. Nat. Struct. Mol. Biol. 2017, 24, 395-406. [CrossRef]

13. Cachot, A.; Bilous, M.; Liu, Y.C.; Li, X.; Saillard, M.; Cenerenti, M.; Rockinger, G.A.; Wyss, T.; Guillaume, P.; Schmidt, J.; et al. Tumor-specific cytolytic CD4 T cells mediate immunity against human cancer. Sci. Adv. 2021, 7, eabe3348. [CrossRef]

14. Dash, P.; Fiore-Gartland, A.J.; Hertz, T.; Wang, G.C.; Sharma, S.; Souquette, A.; Crawford, J.C.; Clemens, E.B.; Nguyen, T.H.O.; Kedzierska, K.; et al. Quantifiable predictive features define epitope-specific T cell receptor repertoires. Nature 2017, 547, 89-93. [CrossRef] [PubMed]

15. Jokinen, E.; Huuhtanen, J.; Mustjoki, S.; Heinonen, M.; Lahdesmaki, H. Predicting recognition between T cell receptors and epitopes with TCRGP. PLoS Comput. Biol. 2021, 17, e1008814. [CrossRef] [PubMed]

16. Mei, S.; Li, F.; Leier, A.; Marquez-Lago, T.T.; Giam, K.; Croft, N.P.; Akutsu, T.; Smith, A.I.; Li, J.; Rossjohn, J.; et al. A comprehensive review and performance evaluation of bioinformatics tools for HLA class I peptide-binding prediction. Brief. Bioinform. 2020, 21, 1119-1135. [CrossRef]

17. Van Rooij, N.; van Buuren, M.M.; Philips, D.; Velds, A.; Toebes, M.; Heemskerk, B.; van Dijk, L.J.; Behjati, S.; Hilkmann, H.; El Atmioui, D.; et al. Tumor exome analysis reveals neoantigen-specific T-cell reactivity in an ipilimumab-responsive melanoma. $J$. Clin. Oncol. 2013, 31, e439-442. [CrossRef]

18. Ferretti, A.P.; Kula, T.; Wang, Y.; Nguyen, D.M.V.; Weinheimer, A.; Dunlap, G.S.; Xu, Q.; Nabilsi, N.; Perullo, C.R.; Cristofaro, A.W.; et al. Unbiased Screens Show CD8(+) T Cells of COVID-19 Patients Recognize Shared Epitopes in SARS-CoV-2 that Largely Reside outside the Spike Protein. Immunity 2020, 53, 1095-1107.e93. [CrossRef]

19. Gonzalez-Galarza, F.F.; McCabe, A.; Santos, E.; Jones, J.; Takeshita, L.; Ortega-Rivera, N.D.; Cid-Pavon, G.M.D.; Ramsbottom, K.; Ghattaoraya, G.; Alfirevic, A.; et al. Allele frequency net database (AFND) 2020 update: Gold-standard data classification, open access genotype data and new query tools. Nucleic Acids Res. 2020, 48, D783-D788. [CrossRef] [PubMed]

20. Maiers, M.; Gragert, L.; Klitz, W. High-resolution HLA alleles and haplotypes in the United States population. Hum. Immunol. 2007, 68, 779-788. [CrossRef]

21. Qazilbash, M.H.; Wieder, E.; Thall, P.F.; Wang, X.; Rios, R.; Lu, S.; Kanodia, S.; Ruisaard, K.E.; Giralt, S.A.; Estey, E.H.; et al. PR1 peptide vaccine induces specific immunity with clinical responses in myeloid malignancies. Leukemia 2017, 31, 697-704. [CrossRef]

22. Gross, S.; Lennerz, V.; Gallerani, E.; Mach, N.; Bohm, S.; Hess, D.; von Boehmer, L.; Knuth, A.; Ochsenbein, A.; Gnad-Vogt, U.; et al. Short Peptide Vaccine Induces CD4+ T Helper Cells in Patients with Different Solid Cancers. Cancer Immunol. Res. 2016, 4, 18-25. [CrossRef] [PubMed]

23. Fukuda, K.; Funakoshi, T.; Sakurai, T.; Nakamura, Y.; Mori, M.; Tanese, K.; Tanikawa, A.; Taguchi, J.; Fujita, T.; Okamoto, M.; et al. Peptide-pulsed dendritic cell vaccine in combination with carboplatin and paclitaxel chemotherapy for stage IV melanoma. Melanoma Res. 2017, 27, 326-334. [CrossRef] [PubMed]

24. Slingluff, C.L., Jr.; Petroni, G.R.; Chianese-Bullock, K.A.; Smolkin, M.E.; Ross, M.I.; Haas, N.B.; von Mehren, M.; Grosh, W.W. Randomized multicenter trial of the effects of melanoma-associated helper peptides and cyclophosphamide on the immunogenicity of a multipeptide melanoma vaccine. J. Clin. Oncol. 2011, 29, 2924-2932. [CrossRef]

25. Sahin, U.; Derhovanessian, E.; Miller, M.; Kloke, B.P.; Simon, P.; Lower, M.; Bukur, V.; Tadmor, A.D.; Luxemburger, U.; Schrors, B.; et al. Personalized RNA mutanome vaccines mobilize poly-specific therapeutic immunity against cancer. Nature 2017, 547, 222-226. [CrossRef]

26. Ott, P.A.; Hu, Z.; Keskin, D.B.; Shukla, S.A.; Sun, J.; Bozym, D.J.; Zhang, W.; Luoma, A.; Giobbie-Hurder, A.; Peter, L.; et al. An immunogenic personal neoantigen vaccine for patients with melanoma. Nature 2017, 547, 217-221. [CrossRef] [PubMed] 
27. Hilf, N.; Kuttruff-Coqui, S.; Frenzel, K.; Bukur, V.; Stevanovic, S.; Gouttefangeas, C.; Platten, M.; Tabatabai, G.; Dutoit, V.; van der Burg, S.H.; et al. Actively personalized vaccination trial for newly diagnosed glioblastoma. Nature 2019, 565, 240-245. [CrossRef] [PubMed]

28. Want, M.Y.; Konstorum, A.; Huang, R.Y.; Jain, V.; Matsueda, S.; Tsuji, T.; Lugade, A.; Odunsi, K.; Koya, R.; Battaglia, S. Neoantigens retention in patient derived xenograft models mediates autologous T cells activation in ovarian cancer. Oncoimmunology 2019, 8, e1586042. [CrossRef]

29. Nielsen, M.; Lund, O.; Buus, S.; Lundegaard, C. MHC class II epitope predictive algorithms. Immunology 2010, 130, 319-328. [CrossRef]

30. Bulik-Sullivan, B.; Busby, J.; Palmer, C.D.; Davis, M.J.; Murphy, T.; Clark, A.; Busby, M.; Duke, F.; Yang, A.; Young, L.; et al. Deep learning using tumor HLA peptide mass spectrometry datasets improves neoantigen identification. Nat. Biotechnol. 2018, 37, 55-63. [CrossRef] [PubMed]

31. Lam, H.; McNeil, L.K.; Starobinets, H.; DeVault, V.L.; Cohen, R.B.; Twardowski, P.; Johnson, M.L.; Gillison, M.L.; Stein, M.N.; Vaishampayan, U.N.; et al. An Empirical Antigen Selection Method Identifies Neoantigens That Either Elicit Broad Antitumor T-cell Responses or Drive Tumor Growth. Cancer Discov. 2021, 11, 696-713. [CrossRef]

32. Finn, O.J.; Rammensee, H.G. Is It Possible to Develop Cancer Vaccines to Neoantigens, What Are the Major Challenges, and How Can These Be Overcome? Neoantigens: Nothing New in Spite of the Name. Cold Spring Harb. Perspect. Biol. 2018,10 , a028829. [CrossRef]

33. Eisenhauer, E.A.; Therasse, P.; Bogaerts, J.; Schwartz, L.H.; Sargent, D.; Ford, R.; Dancey, J.; Arbuck, S.; Gwyther, S.; Mooney, M.; et al. New response evaluation criteria in solid tumours: Revised RECIST guideline (version 1.1). Eur. J. Cancer 2009, 45, $228-247$. [CrossRef] [PubMed]

34. Julka, P.K.; Doval, D.C.; Gupta, S.; Rath, G.K. Response assessment in solid tumours: A comparison of WHO, SWOG and RECIST guidelines. Br. J. Radiol. 2008, 81, 444-449. [CrossRef]

35. Durie, B.G.; Harousseau, J.L.; Miguel, J.S.; Blade, J.; Barlogie, B.; Anderson, K.; Gertz, M.; Dimopoulos, M.; Westin, J.; Sonneveld, P.; et al. International uniform response criteria for multiple myeloma. Leukemia 2006, 20, 1467-1473. [CrossRef] [PubMed]

36. Silverman, L.R.; Demakos, E.P.; Peterson, B.L.; Kornblith, A.B.; Holland, J.C.; Odchimar-Reissig, R.; Stone, R.M.; Nelson, D.; Powell, B.L.; DeCastro, C.M.; et al. Randomized controlled trial of azacitidine in patients with the myelodysplastic syndrome: A study of the cancer and leukemia group B. J. Clin. Oncol. 2002, 20, 2429-2440. [CrossRef] [PubMed]

37. Dillon, P.M.; Petroni, G.R.; Smolkin, M.E.; Brenin, D.R.; Chianese-Bullock, K.A.; Smith, K.T.; Olson, W.C.; Fanous, I.S.; Nail, C.J.; Brenin, C.M.; et al. A pilot study of the immunogenicity of a 9-peptide breast cancer vaccine plus poly-ICLC in early stage breast cancer. J. Immunother. Cancer 2017, 5, 92-101. [CrossRef]

38. Nakagawa, H.; Mizukoshi, E.; Kobayashi, E.; Tamai, T.; Hamana, H.; Ozawa, T.; Kishi, H.; Kitahara, M.; Yamashita, T.; Arai, K.; et al. Association Between High-Avidity T-Cell Receptors, Induced by alpha-Fetoprotein-Derived Peptides, and Anti-Tumor Effects in Patients With Hepatocellular Carcinoma. Gastroenterology 2017, 152, 1395-1406. [CrossRef]

39. Mehrotra, S.; Britten, C.D.; Chin, S.; Garrett-Mayer, E.; Cloud, C.A.; Li, M.; Scurti, G.; Salem, M.L.; Nelson, M.H.; Thomas, M.B.; et al. Vaccination with poly(IC:LC) and peptide-pulsed autologous dendritic cells in patients with pancreatic cancer. J. Hematol. Oncol. 2017, 10, 82-94. [CrossRef]

40. Banchereau, J.; Palucka, A.K.; Dhodapkar, M.; Burkeholder, S.; Taquet, N.; Rolland, A.; Taquet, S.; Coquery, S.; Wittkowski, K.M.; Bhardwaj, N.; et al. Immune and clinical responses in patients with metastatic melanoma to CD34(+) progenitor-derived dendritic cell vaccine. Cancer Res. 2001, 61, 6451-6458.

41. Rausch, S.; Schwentner, C.; Stenzl, A.; Bedke, J. mRNA vaccine CV9103 and CV9104 for the treatment of prostate cancer. Hum. Vaccin. Immunother. 2014, 10, 3146-3152. [CrossRef]

42. Kubler, H.; Scheel, B.; Gnad-Vogt, U.; Miller, K.; Schultze-Seemann, W.; Vom Dorp, F.; Parmiani, G.; Hampel, C.; Wedel, S.; Trojan, L.; et al. Self-adjuvanted mRNA vaccination in advanced prostate cancer patients: A first-in-man phase I/IIa study. J. Immunother. Cancer 2015, 3, 26-39. [CrossRef]

43. Karkada, M.; Berinstein, N.L.; Mansour, M. Therapeutic vaccines and cancer: Focus on DPX-0907. Biologics 2014, 8, 27-38. [CrossRef] [PubMed]

44. Berinstein, N.L.; Karkada, M.; Morse, M.A.; Nemunaitis, J.J.; Chatta, G.; Kaufman, H.; Odunsi, K.; Nigam, R.; Sammatur, L.; MacDonald, L.D.; et al. First-in-man application of a novel therapeutic cancer vaccine formulation with the capacity to induce multi-functional T cell responses in ovarian, breast and prostate cancer patients. J. Transl. Med. 2012, 10, 156-168. [CrossRef] [PubMed]

45. Ponomarenko, D.M.; Klimova, I.D.; Chapygina, Y.A.; Dvornichenko, V.V.; Zhukova, N.V.; Orlova, R.V.; Manikhas, G.M.; Zyryanov, A.V.; Burkhanova, L.A.; Badrtdinova, I.I.; et al. Safety and efficacy of p62 DNA vaccine ELENAGEN in a first-in-human trial in patients with advanced solid tumors. Oncotarget 2017, 8, 53730-53739. [CrossRef] [PubMed]

46. Murahashi, M.; Hijikata, Y.; Yamada, K.; Tanaka, Y.; Kishimoto, J.; Inoue, H.; Marumoto, T.; Takahashi, A.; Okazaki, T.; Takeda, K.; et al. Phase I clinical trial of a five-peptide cancer vaccine combined with cyclophosphamide in advanced solid tumors. Clin. Immunol. 2016, 166-167, 48-58. [CrossRef] [PubMed]

47. Pollack, I.F.; Jakacki, R.I.; Butterfield, L.H.; Hamilton, R.L.; Panigrahy, A.; Normolle, D.P.; Connelly, A.K.; Dibridge, S.; Mason, G.; Whiteside, T.L.; et al. Immune responses and outcome after vaccination with glioma-associated antigen peptides and poly-ICLC in a pilot study for pediatric recurrent low-grade gliomas. Neuro-Oncol. 2016, 18, 1157-1168. [CrossRef] [PubMed] 
48. Pollack, I.F.; Jakacki, R.I.; Butterfield, L.H.; Hamilton, R.L.; Panigrahy, A.; Potter, D.M.; Connelly, A.K.; Dibridge, S.A.; Whiteside, T.L.; Okada, H. Antigen-specific immune responses and clinical outcome after vaccination with glioma-associated antigen peptides and polyinosinic-polycytidylic acid stabilized by lysine and carboxymethylcellulose in children with newly diagnosed malignant brainstem and nonbrainstem gliomas. J. Clin. Oncol. 2014, 32, 2050-2058. [CrossRef]

49. Voskens, C.J.; Sewell, D.; Hertzano, R.; DeSanto, J.; Rollins, S.; Lee, M.; Taylor, R.; Wolf, J.; Suntharalingam, M.; Gastman, B.; et al. Induction of MAGE-A3 and HPV-16 immunity by Trojan vaccines in patients with head and neck carcinoma. Head Neck 2012, 34, 1734-1746. [CrossRef]

50. Rapoport, A.P.; Aqui, N.A.; Stadtmauer, E.A.; Vogl, D.T.; Xu, Y.Y.; Kalos, M.; Cai, L.; Fang, H.B.; Weiss, B.M.; Badros, A.; et al. Combination immunotherapy after ASCT for multiple myeloma using MAGE-A3/Poly-ICLC immunizations followed by adoptive transfer of vaccine-primed and costimulated autologous T cells. Clin. Cancer Res. 2014, 20, 1355-1365. [CrossRef]

51. Zandberg, D.P.; Rollins, S.; Goloubeva, O.; Morales, R.E.; Tan, M.; Taylor, R.; Wolf, J.S.; Schumaker, L.M.; Cullen, K.J.; Zimrin, A.; et al. A phase I dose escalation trial of MAGE-A3- and HPV16-specific peptide immunomodulatory vaccines in patients with recurrent/metastatic (RM) squamous cell carcinoma of the head and neck (SCCHN). Cancer Immunol. Immunother. 2015, 64, 367-379. [CrossRef] [PubMed]

52. Tsuchiya, N.; Hosono, A.; Yoshikawa, T.; Shoda, K.; Nosaka, K.; Shimomura, M.; Hara, J.; Nitani, C.; Manabe, A.; Yoshihara, H.; et al. Phase I study of glypican-3-derived peptide vaccine therapy for patients with refractory pediatric solid tumors. Oncoimmunology 2017, 7, e1377872. [CrossRef]

53. Tsuchiya, N.; Yoshikawa, T.; Fujinami, N.; Saito, K.; Mizuno, S.; Sawada, Y.; Endo, I.; Nakatsura, T. Immunological efficacy of glypican-3 peptide vaccine in patients with advanced hepatocellular carcinoma. Oncoimmunology 2017, 6, e1346764. [CrossRef] [PubMed]

54. Fenoglio, D.; Traverso, P.; Parodi, A.; Tomasello, L.; Negrini, S.; Kalli, F.; Battaglia, F.; Ferrera, F.; Sciallero, S.; Murdaca, G.; et al. A multi-peptide, dual-adjuvant telomerase vaccine (GX301) is highly immunogenic in patients with prostate and renal cancer. Cancer Immunol. Immunother. 2013, 62, 1041-1052. [CrossRef]

55. Caballero, I.; Aira, L.E.; Lavastida, A.; Popa, X.; Rivero, J.; Gonzalez, J.; Mesa, M.; Gonzalez, N.; Coba, K.; Lorenzo-Luaces, P.; et al. Safety and Immunogenicity of a Human Epidermal Growth Factor Receptor 1 (HER1)-Based Vaccine in Prostate Castration-Resistant Carcinoma Patients: A Dose-Escalation Phase I Study Trial. Front. Pharm. 2017, 8, 263-268. [CrossRef]

56. Bekaii-Saab, T.; Wesolowski, R.; Ahn, D.H.; Wu, C.; Mortazavi, A.; Lustberg, M.B.; Ramaswamy, B.; Fowler, J.; Wei, L.; Overholser, J.; et al. Phase 1 Immunotherapy Trial with Two Chimeric HER-2 B-Cell Peptide Vaccines emulsified in Montanide ISA 720VG and nor-MDP Adjuvant in Advanced Solid Tumors. Clin. Cancer Res. 2019, 25, 3495-3507. [CrossRef] [PubMed]

57. Knutson, K.L.; Schiffman, K.; Disis, M.L. Immunization with a HER-2/neu helper peptide vaccine generates HER-2/neu CD8 T-cell immunity in cancer patients. J. Clin. Investig. 2001, 107, 477-484. [CrossRef]

58. Gudmundsdotter, L.; Wahren, B.; Haller, B.K.; Boberg, A.; Edback, U.; Bernasconi, D.; Butto, S.; Gaines, H.; Imami, N.; Gotch, F.; et al. Amplified antigen-specific immune responses in HIV-1 infected individuals in a double blind DNA immunization and therapy interruption trial. Vaccine 2011, 29, 5558-5566. [CrossRef]

59. Kenter, G.G.; Welters, M.J.; Valentijn, A.R.; Lowik, M.J.; Berends-van der Meer, D.M.; Vloon, A.P.; Essahsah, F.; Fathers, L.M.; Offringa, R.; Drijfhout, J.W.; et al. Vaccination against HPV-16 oncoproteins for vulvar intraepithelial neoplasia. New Engl. J. Med. 2009, 361, 1838-1847. [CrossRef]

60. Welters, M.J.; Kenter, G.G.; Piersma, S.J.; Vloon, A.P.; Lowik, M.J.; Berends-van der Meer, D.M.; Drijfhout, J.W.; Valentijn, A.R.; Wafelman, A.R.; Oostendorp, J.; et al. Induction of tumor-specific CD4+ and CD8+ T-cell immunity in cervical cancer patients by a human papillomavirus type 16 E6 and E7 long peptides vaccine. Clin. Cancer Res. 2008, 14, 178-187. [CrossRef]

61. Massarelli, E.; William, W.; Johnson, F.; Kies, M.; Ferrarotto, R.; Guo, M.; Feng, L.; Lee, J.J.; Tran, H.; Kim, Y.U.; et al. Combining Immune Checkpoint Blockade and Tumor-Specific Vaccine for Patients With Incurable Human Papillomavirus 16-Related Cancer: A Phase 2 Clinical Trial. JAMA Oncol. 2018, 5, 67-73. [CrossRef]

62. Phuphanich, S.; Wheeler, C.J.; Rudnick, J.D.; Mazer, M.; Wang, H.; Nuno, M.A.; Richardson, J.E.; Fan, X.; Ji, J.; Chu, R.M.; et al. Phase I trial of a multi-epitope-pulsed dendritic cell vaccine for patients with newly diagnosed glioblastoma. Cancer Immunol. Immunother. 2013, 62, 125-135. [CrossRef] [PubMed]

63. Nitschke, N.J.; Bjoern, J.; Iversen, T.Z.; Andersen, M.H.; Svane, I.M. Indoleamine 2,3-dioxygenase and survivin peptide vaccine combined with temozolomide in metastatic melanoma. Stem Cell Investig. 2017, 4, 77. [CrossRef] [PubMed]

64. Bjoern, J.; Iversen, T.Z.; Nitschke, N.J.; Andersen, M.H.; Svane, I.M. Safety, immune and clinical responses in metastatic melanoma patients vaccinated with a long peptide derived from indoleamine 2,3-dioxygenase in combination with ipilimumab. Cytotherapy 2016, 18, 1043-1055. [CrossRef] [PubMed]

65. Migliorini, D.; Dutoit, V.; Allard, M.; Grandjean Hallez, N.; Marinari, E.; Widmer, V.; Philippin, G.; Corlazzoli, F.; Gustave, R.; Kreutzfeldt, M.; et al. Phase I/II trial testing safety and immunogenicity of the multipeptide IMA950/poly-ICLC vaccine in newly diagnosed adult malignant astrocytoma patients. Neuro-Oncol. 2019, 21, 923-933. [CrossRef]

66. Dutoit, V.; Migliorini, D.; Ranzanici, G.; Marinari, E.; Widmer, V.; Lobrinus, J.A.; Momjian, S.; Costello, J.; Walker, P.R.; Okada, H.; et al. Antigenic expression and spontaneous immune responses support the use of a selected peptide set from the IMA950 glioblastoma vaccine for immunotherapy of grade II and III glioma. Oncoimmunology 2018, 7, e1391972. [CrossRef] 
67. Rampling, R.; Peoples, S.; Mulholland, P.J.; James, A.; Al-Salihi, O.; Twelves, C.J.; McBain, C.; Jefferies, S.; Jackson, A.; Stewart, W.; et al. A Cancer Research UK First Time in Human Phase I Trial of IMA950 (Novel Multipeptide Therapeutic Vaccine) in Patients with Newly Diagnosed Glioblastoma. Clin. Cancer Res. 2016, 22, 4776-4785. [CrossRef]

68. Carmon, L.; Avivi, I.; Kovjazin, R.; Zuckerman, T.; Dray, L.; Gatt, M.E.; Or, R.; Shapira, M.Y. Phase I/II study exploring ImMucin, a pan-major histocompatibility complex, anti-MUC1 signal peptide vaccine, in multiple myeloma patients. Br. J. Haematol. 2015, 169, 44-56. [CrossRef]

69. Kovjazin, R.; Volovitz, I.; Kundel, Y.; Rosenbaum, E.; Medalia, G.; Horn, G.; Smorodinsky, N.I.; Brenner, B.; Carmon, L. ImMucin: A novel therapeutic vaccine with promiscuous MHC binding for the treatment of MUC1-expressing tumors. Vaccine 2011, 29, 4676-4686. [CrossRef]

70. Legat, A.; Maby-El Hajjami, H.; Baumgaertner, P.; Cagnon, L.; Abed Maillard, S.; Geldhof, C.; Iancu, E.M.; Lebon, L.; Guillaume, P.; Dojcinovic, D.; et al. Vaccination with LAG-3Ig (IMP321) and Peptides Induces Specific CD4 and CD8 T-Cell Responses in Metastatic Melanoma Patients-Report of a Phase I/IIa Clinical Trial. Clin. Cancer Res. 2016, 22, 1330-1340. [CrossRef] [PubMed]

71. Chiappori, A.A.; Soliman, H.; Janssen, W.E.; Antonia, S.J.; Gabrilovich, D.I. INGN-225: A dendritic cell-based p53 vaccine (Ad.p53-DC) in small cell lung cancer: Observed association between immune response and enhanced chemotherapy effect. Expert Opin. Biol. 2010, 10, 983-991. [CrossRef]

72. Asahara, S.; Takeda, K.; Yamao, K.; Maguchi, H.; Yamaue, H. Phase I/II clinical trial using HLA-A24-restricted peptide vaccine derived from KIF20A for patients with advanced pancreatic cancer. J. Transl. Med. 2013, 11, 291-304. [CrossRef] [PubMed]

73. Noguchi, M.; Arai, G.; Matsumoto, K.; Naito, S.; Moriya, F.; Suekane, S.; Komatsu, N.; Matsueda, S.; Sasada, T.; Yamada, A.; et al. Phase I trial of a cancer vaccine consisting of 20 mixed peptides in patients with castration-resistant prostate cancer: Dose-related immune boosting and suppression. Cancer Immunol. Immunother. 2015, 64, 493-505. [CrossRef] [PubMed]

74. Wang, F.; Bade, E.; Kuniyoshi, C.; Spears, L.; Jeffery, G.; Marty, V.; Groshen, S.; Weber, J. Phase I trial of a MART-1 peptide vaccine with incomplete Freund's adjuvant for resected high-risk melanoma. Clin. Cancer Res. 1999, 5, 2756-2765.

75. Slingluff, C.L., Jr.; Petroni, G.R.; Yamshchikov, G.V.; Barnd, D.L.; Eastham, S.; Galavotti, H.; Patterson, J.W.; Deacon, D.H.; Hibbitts, S.; Teates, D.; et al. Clinical and immunologic results of a randomized phase II trial of vaccination using four melanoma peptides either administered in granulocyte-macrophage colony-stimulating factor in adjuvant or pulsed on dendritic cells. J. Clin. Oncol. 2003, 21, 4016-4026. [CrossRef] [PubMed]

76. Hasegawa, K.; Ikeda, Y.; Kunugi, Y.; Kurosaki, A.; Imai, Y.; Kohyama, S.; Nagao, S.; Kozawa, E.; Yoshida, K.; Tsunoda, T.; et al. Phase I Study of Multiple Epitope Peptide Vaccination in Patients With Recurrent or Persistent Cervical Cancer. J. Immunother. 2018, 41, 201-207. [CrossRef] [PubMed]

77. Wada, H.; Isobe, M.; Kakimi, K.; Mizote, Y.; Eikawa, S.; Sato, E.; Takigawa, N.; Kiura, K.; Tsuji, K.; Iwatsuki, K.; et al. Vaccination with NY-ESO-1 overlapping peptides mixed with Picibanil OK-432 and montanide ISA-51 in patients with cancers expressing the NY-ESO-1 antigen. J. Immunother. 2014, 37, 84-92. [CrossRef]

78. Sabbatini, P.; Tsuji, T.; Ferran, L.; Ritter, E.; Sedrak, C.; Tuballes, K.; Jungbluth, A.A.; Ritter, G.; Aghajanian, C.; Bell-McGuinn, K.; et al. Phase I trial of overlapping long peptides from a tumor self-antigen and poly-ICLC shows rapid induction of integrated immune response in ovarian cancer patients. Clin. Cancer Res. 2012, 18, 6497-6508. [CrossRef]

79. Kakimi, K.; Isobe, M.; Uenaka, A.; Wada, H.; Sato, E.; Doki, Y.; Nakajima, J.; Seto, Y.; Yamatsuji, T.; Naomoto, Y.; et al. A phase I study of vaccination with NY-ESO-1f peptide mixed with Picibanil OK-432 and Montanide ISA-51 in patients with cancers expressing the NY-ESO-1 antigen. Int. J. Cancer 2011, 129, 2836-2846. [CrossRef]

80. Taniguchi, H.; Iwasa, S.; Yamazaki, K.; Yoshino, T.; Kiryu, C.; Naka, Y.; Liew, E.L.; Sakata, Y. Phase 1 study of OCV-C02, a peptide vaccine consisting of two peptide epitopes for refractory metastatic colorectal cancer. Cancer Sci. 2017, 108, 1013-1021. [CrossRef] [PubMed]

81. Zeestraten, E.C.; Speetjens, F.M.; Welters, M.J.; Saadatmand, S.; Stynenbosch, L.F.; Jongen, R.; Kapiteijn, E.; Gelderblom, H.; Nijman, H.W.; Valentijn, A.R.; et al. Addition of interferon-alpha to the p53-SLP(R) vaccine results in increased production of interferon-gamma in vaccinated colorectal cancer patients: A phase I/II clinical trial. Int. J. Cancer 2013, 132, $1581-1591$. [CrossRef] [PubMed]

82. Speetjens, F.M.; Kuppen, P.J.; Welters, M.J.; Essahsah, F.; Voet van den Brink, A.M.; Lantrua, M.G.; Valentijn, A.R.; Oostendorp, J.; Fathers, L.M.; Nijman, H.W.; et al. Induction of p53-specific immunity by a p53 synthetic long peptide vaccine in patients treated for metastatic colorectal cancer. Clin. Cancer Res. 2009, 15, 1086-1095. [CrossRef] [PubMed]

83. Vermeij, R.; Leffers, N.; Hoogeboom, B.N.; Hamming, I.L.; Wolf, R.; Reyners, A.K.; Molmans, B.H.; Hollema, H.; Bart, J.; Drijfhout, J.W.; et al. Potentiation of a p53-SLP vaccine by cyclophosphamide in ovarian cancer: A single-arm phase II study. Int. J. Cancer 2012, 131, E670-E680. [CrossRef] [PubMed]

84. Leffers, N.; Lambeck, A.J.; Gooden, M.J.; Hoogeboom, B.N.; Wolf, R.; Hamming, I.E.; Hepkema, B.G.; Willemse, P.H.; Molmans, B.H.; Hollema, H.; et al. Immunization with a P53 synthetic long peptide vaccine induces P53-specific immune responses in ovarian cancer patients, a phase II trial. Int. J. Cancer 2009, 125, 2104-2113. [CrossRef]

85. Hardwick, N.R.; Frankel, P.; Ruel, C.; Kilpatrick, J.; Tsai, W.; Kos, F.; Kaltcheva, T.; Leong, L.; Morgan, R.; Chung, V.; et al. p53-Reactive T Cells Are Associated with Clinical Benefit in Patients with Platinum-Resistant Epithelial Ovarian Cancer After Treatment with a p53 Vaccine and Gemcitabine Chemotherapy. Clin. Cancer Res. 2018, 24, 1315-1325. [CrossRef] 
86. Greenfield, W.W.; Stratton, S.L.; Myrick, R.S.; Vaughn, R.; Donnalley, L.M.; Coleman, H.N.; Mercado, M.; Moerman-Herzog, A.M.; Spencer, H.J.; Andrews-Collins, N.R.; et al. A phase I dose-escalation clinical trial of a peptide-based human papillomavirus therapeutic vaccine with Candida skin test reagent as a novel vaccine adjuvant for treating women with biopsy-proven cervical intraepithelial neoplasia 2/3. Oncoimmunology 2015, 4, e1031439. [CrossRef]

87. Suzuki, N.; Hazama, S.; Iguchi, H.; Uesugi, K.; Tanaka, H.; Hirakawa, K.; Aruga, A.; Hatori, T.; Ishizaki, H.; Umeda, Y.; et al. Phase II clinical trial of peptide cocktail therapy for patients with advanced pancreatic cancer: VENUS-PC study. Cancer Sci. 2017, 108, 73-80. [CrossRef]

88. Kawamura, J.; Sugiura, F.; Sukegawa, Y.; Yoshioka, Y.; Hida, J.I.; Hazama, S.; Okuno, K. Cytotoxic T lymphocyte response to peptide vaccination predicts survival in stage III colorectal cancer. Cancer Sci. 2018, 109, 1545-1551. [CrossRef]

89. Yoshitake, Y.; Fukuma, D.; Yuno, A.; Hirayama, M.; Nakayama, H.; Tanaka, T.; Nagata, M.; Takamune, Y.; Kawahara, K.; Nakagawa, Y.; et al. Phase II clinical trial of multiple peptide vaccination for advanced head and neck cancer patients revealed induction of immune responses and improved OS. Clin. Cancer Res. 2015, 21, 312-321. [CrossRef]

90. Rezvani, K.; Yong, A.S.; Mielke, S.; Jafarpour, B.; Savani, B.N.; Le, R.Q.; Eniafe, R.; Musse, L.; Boss, C.; Kurlander, R.; et al. Repeated PR1 and WT1 peptide vaccination in Montanide-adjuvant fails to induce sustained high-avidity, epitope-specific CD8+ T cells in myeloid malignancies. Haematologica 2011, 96, 432-440. [CrossRef] [PubMed]

91. Alvarez, R.D.; Huh, W.K.; Bae, S.; Lamb, L.S., Jr.; Conner, M.G.; Boyer, J.; Wang, C.; Hung, C.F.; Sauter, E.; Paradis, M.; et al. A pilot study of pNGVL4a-CRT/E7(detox) for the treatment of patients with HPV16+ cervical intraepithelial neoplasia $2 / 3$ (CIN2/3). Gynecol. Oncol. 2016, 140, 245-252. [CrossRef]

92. Arlen, P.M.; Skarupa, L.; Pazdur, M.; Seetharam, M.; Tsang, K.Y.; Grosenbach, D.W.; Feldman, J.; Poole, D.J.; Litzinger, M.; Steinberg, S.M.; et al. Clinical safety of a viral vector based prostate cancer vaccine strategy. J. Urol. 2007, 178, 1515-1520. [CrossRef] [PubMed]

93. Arlen, P.M.; Gulley, J.L.; Todd, N.; Lieberman, R.; Steinberg, S.M.; Morin, S.; Bastian, A.; Marte, J.; Tsang, K.Y.; Beetham, P.; et al. Antiandrogen, vaccine and combination therapy in patients with nonmetastatic hormone refractory prostate cancer. J. Urol. 2005, 174, 539-546. [CrossRef] [PubMed]

94. Madan, R.A.; Mohebtash, M.; Arlen, P.M.; Vergati, M.; Rauckhorst, M.; Steinberg, S.M.; Tsang, K.Y.; Poole, D.J.; Parnes, H.L.; Wright, J.J.; et al. Ipilimumab and a poxviral vaccine targeting prostate-specific antigen in metastatic castration-resistant prostate cancer: A phase 1 dose-escalation trial. Lancet Oncol. 2012, 13, 501-508. [CrossRef]

95. Gulley, J.L.; Arlen, P.M.; Bastian, A.; Morin, S.; Marte, J.; Beetham, P.; Tsang, K.Y.; Yokokawa, J.; Hodge, J.W.; Menard, C.; et al. Combining a recombinant cancer vaccine with standard definitive radiotherapy in patients with localized prostate cancer. Clin. Cancer Res. 2005, 11, 3353-3362. [CrossRef]

96. Lechleider, R.J.; Arlen, P.M.; Tsang, K.Y.; Steinberg, S.M.; Yokokawa, J.; Cereda, V.; Camphausen, K.; Schlom, J.; Dahut, W.L.; Gulley, J.L. Safety and immunologic response of a viral vaccine to prostate-specific antigen in combination with radiation therapy when metronomic-dose interleukin 2 is used as an adjuvant. Clin. Cancer Res. 2008, 14, 5284-5291. [CrossRef] [PubMed]

97. Gulley, J.L.; Arlen, P.M.; Madan, R.A.; Tsang, K.Y.; Pazdur, M.P.; Skarupa, L.; Jones, J.L.; Poole, D.J.; Higgins, J.P.; Hodge, J.W.; et al. Immunologic and prognostic factors associated with overall survival employing a poxviral-based PSA vaccine in metastatic castrate-resistant prostate cancer. Cancer Immunol. Immunother. 2010, 59, 663-674. [CrossRef] [PubMed]

98. Xi, H.B.; Wang, G.X.; Fu, B.; Liu, W.P.; Li, Y. Survivin and PSMA Loaded Dendritic Cell Vaccine for the Treatment of Prostate Cancer. Biol. Pharm. Bull. 2015, 38, 827-835. [CrossRef]

99. Nooka, A.K.; Wang, M.L.; Yee, A.J.; Kaufman, J.L.; Bae, J.; Peterkin, D.; Richardson, P.G.; Raje, N.S. Assessment of Safety and Immunogenicity of PVX-410 Vaccine With or Without Lenalidomide in Patients With Smoldering Multiple Myeloma: A Nonrandomized Clinical Trial. JAMA Oncol. 2018, 4, e183267. [CrossRef]

100. Greiner, J.; Schmitt, A.; Giannopoulos, K.; Rojewski, M.T.; Gotz, M.; Funk, I.; Ringhoffer, M.; Bunjes, D.; Hofmann, S.; Ritter, G.; et al. High-dose RHAMM-R3 peptide vaccination for patients with acute myeloid leukemia, myelodysplastic syndrome and multiple myeloma. Haematologica 2010, 95, 1191-1197. [CrossRef] [PubMed]

101. Obara, W.; Ohsawa, R.; Kanehira, M.; Takata, R.; Tsunoda, T.; Yoshida, K.; Takeda, K.; Katagiri, T.; Nakamura, Y.; Fujioka, T. Cancer peptide vaccine therapy developed from oncoantigens identified through genome-wide expression profile analysis for bladder cancer. Jpn. J. Clin. Oncol. 2012, 42, 591-600. [CrossRef]

102. Butts, C.; Murray, N.; Maksymiuk, A.; Goss, G.; Marshall, E.; Soulieres, D.; Cormier, Y.; Ellis, P.; Price, A.; Sawhney, R.; et al. Randomized phase IIB trial of BLP25 liposome vaccine in stage IIIB and IV non-small-cell lung cancer. J. Clin. Oncol. 2005, 23, 6674-6681. [CrossRef] [PubMed]

103. Satomi, F. Phase I Clinical Study of Survivin-Derived Peptide Vaccine for Patients with Advanced Gastrointestinal Cancers. Int J. Cancer Clin. Res. 2015, 2, 12. [CrossRef]

104. Tagawa, S.T.; Lee, P.; Snively, J.; Boswell, W.; Ounpraseuth, S.; Lee, S.; Hickingbottom, B.; Smith, J.; Johnson, D.; Weber, J.S. Phase I study of intranodal delivery of a plasmid DNA vaccine for patients with Stage IV melanoma. Cancer 2003, 98, 144-154. [CrossRef]

105. Wood, L.V.; Fojo, A.; Roberson, B.D.; Hughes, M.S.; Dahut, W.; Gulley, J.L.; Madan, R.A.; Arlen, P.M.; Sabatino, M.; Stroncek, D.F.; et al. TARP vaccination is associated with slowing in PSA velocity and decreasing tumor growth rates in patients with Stage D0 prostate cancer. Oncoimmunology 2016, 5, e1197459. [CrossRef] [PubMed] 
106. Rochlitz, C.; Figlin, R.; Squiban, P.; Salzberg, M.; Pless, M.; Herrmann, R.; Tartour, E.; Zhao, Y.; Bizouarne, N.; Baudin, M.; et al. Phase I immunotherapy with a modified vaccinia virus (MVA) expressing human MUC1 as antigen-specific immunotherapy in patients with MUC1-positive advanced cancer. J. Gene Med. 2003, 5, 690-699. [CrossRef] [PubMed]

107. Dreicer, R.; Stadler, W.M.; Ahmann, F.R.; Whiteside, T.; Bizouarne, N.; Acres, B.; Limacher, J.M.; Squiban, P.; Pantuck, A. MVAMUC1-IL2 vaccine immunotherapy (TG4010) improves PSA doubling time in patients with prostate cancer with biochemical failure. Investig. New Drugs 2009, 27, 379-386. [CrossRef] [PubMed]

108. Oudard, S.; Rixe, O.; Beuselinck, B.; Linassier, C.; Banu, E.; Machiels, J.P.; Baudard, M.; Ringeisen, F.; Velu, T.; Lefrere-Belda, M.A.; et al. A phase II study of the cancer vaccine TG4010 alone and in combination with cytokines in patients with metastatic renal clear-cell carcinoma: Clinical and immunological findings. Cancer Immunol. Immunother. 2011, 60, 261-271. [CrossRef]

109. Ramlau, R.; Quoix, E.; Rolski, J.; Pless, M.; Lena, H.; Levy, E.; Krzakowski, M.; Hess, D.; Tartour, E.; Chenard, M.P.; et al. A phase II study of Tg4010 (Mva-Muc1-Il2) in association with chemotherapy in patients with stage III/IV Non-small cell lung cancer. J. Thorac. Oncol. 2008, 3, 735-744. [CrossRef]

110. Cusi, M.G.; Botta, C.; Pastina, P.; Rossetti, M.G.; Dreassi, E.; Guidelli, G.M.; Fioravanti, A.; Martino, E.C.; Gandolfo, C.; Pagliuchi, M.; et al. Phase I trial of thymidylate synthase poly-epitope peptide (TSPP) vaccine in advanced cancer patients. Cancer Immunol. Immunother. 2015, 64, 1159-1173. [CrossRef] [PubMed]

111. Correale, P.; Botta, C.; Martino, E.C.; Ulivieri, C.; Battaglia, G.; Carfagno, T.; Rossetti, M.G.; Fioravanti, A.; Guidelli, G.M.; Cheleschi, S.; et al. Phase Ib study of poly-epitope peptide vaccination to thymidylate synthase (TSPP) and GOLFIG chemoimmunotherapy for treatment of metastatic colorectal cancer patients. Oncoimmunology 2016, 5, e1101205. [CrossRef] [PubMed]

112. Bagarazzi, M.L.; Yan, J.; Morrow, M.P.; Shen, X.; Parker, R.L.; Lee, J.C.; Giffear, M.; Pankhong, P.; Khan, A.S.; Broderick, K.E.; et al. Immunotherapy against HPV16/18 generates potent TH1 and cytotoxic cellular immune responses. Sci. Transl. Med. 2012, 4, 155ra138. [CrossRef] [PubMed]

113. Trimble, C.L.; Morrow, M.P.; Kraynyak, K.A.; Shen, X.; Dallas, M.; Yan, J.; Edwards, L.; Parker, R.L.; Denny, L.; Giffear, M.; et al. Safety, efficacy, and immunogenicity of VGX-3100, a therapeutic synthetic DNA vaccine targeting human papillomavirus 16 and $18 \mathrm{E} 6$ and E7 proteins for cervical intraepithelial neoplasia 2/3: A randomised, double-blind, placebo-controlled phase $2 \mathrm{~b}$ trial. Lancet 2015, 386, 2078-2088. [CrossRef]

114. Vetsika, E.K.; Konsolakis, G.; Aggouraki, D.; Kotsakis, A.; Papadimitraki, E.; Christou, S.; Menez-Jamet, J.; Kosmatopoulos, K.; Georgoulias, V.; Mavroudis, D. Immunological responses in cancer patients after vaccination with the therapeutic telomerasespecific vaccine Vx-001. Cancer Immunol. Immunother. 2012, 61, 157-168. [CrossRef] [PubMed]

115. Kotsakis, A.; Vetsika, E.K.; Christou, S.; Hatzidaki, D.; Vardakis, N.; Aggouraki, D.; Konsolakis, G.; Georgoulias, V.; Christophyllakis, C.; Cordopatis, P.; et al. Clinical outcome of patients with various advanced cancer types vaccinated with an optimized cryptic human telomerase reverse transcriptase (TERT) peptide: Results of an expanded phase II study. Ann. Oncol. 2012, 23, 442-449. [CrossRef] [PubMed]

116. Bolonaki, I.; Kotsakis, A.; Papadimitraki, E.; Aggouraki, D.; Konsolakis, G.; Vagia, A.; Christophylakis, C.; Nikoloudi, I.; Magganas, E.; Galanis, A.; et al. Vaccination of patients with advanced non-small-cell lung cancer with an optimized cryptic human telomerase reverse transcriptase peptide. J. Clin. Oncol. 2007, 25, 2727-2734. [CrossRef] [PubMed]

117. Kotsakis, A.; Papadimitraki, E.; Vetsika, E.K.; Aggouraki, D.; Dermitzaki, E.K.; Hatzidaki, D.; Kentepozidis, N.; Mavroudis, D.; Georgoulias, V. A phase II trial evaluating the clinical and immunologic response of HLA-A2(+) non-small cell lung cancer patients vaccinated with an hTERT cryptic peptide. Lung Cancer 2014, 86, 59-66. [CrossRef] [PubMed]

118. Tsuboi, A.; Hashimoto, N.; Fujiki, F.; Morimoto, S.; Kagawa, N.; Nakajima, H.; Hosen, N.; Nishida, S.; Nakata, J.; Morita, S.; et al. A phase I clinical study of a cocktail vaccine of Wilms' tumor 1 (WT1) HLA class I and II peptides for recurrent malignant glioma. Cancer Immunol. Immunother. 2019, 68, 331-340. [CrossRef]

119. Zhang, W.; Lu, X.; Cui, P.; Piao, C.; Xiao, M.; Liu, X.; Wang, Y.; Wu, X.; Liu, J.; Yang, L. Phase I/II clinical trial of a Wilms' tumor 1 -targeted dendritic cell vaccination-based immunotherapy in patients with advanced cancer. Cancer Immunol. Immunother. 2019, 68, 121-130. [CrossRef]

120. Yanagisawa, R.; Koizumi, T.; Koya, T.; Sano, K.; Koido, S.; Nagai, K.; Kobayashi, M.; Okamoto, M.; Sugiyama, H.; Shimodaira, S. WT1-pulsed Dendritic Cell Vaccine Combined with Chemotherapy for Resected Pancreatic Cancer in a Phase I Study. Anticancer Res. 2018, 38, 2217-2225. [CrossRef]

121. Keilholz, U.; Letsch, A.; Busse, A.; Asemissen, A.M.; Bauer, S.; Blau, I.W.; Hofmann, W.K.; Uharek, L.; Thiel, E.; Scheibenbogen, C. A clinical and immunologic phase 2 trial of Wilms tumor gene product 1 (WT1) peptide vaccination in patients with AML and MDS. Blood 2009, 113, 6541-6548. [CrossRef]

122. Nishida, S.; Ishikawa, T.; Egawa, S.; Koido, S.; Yanagimoto, H.; Ishii, J.; Kanno, Y.; Kokura, S.; Yasuda, H.; Oba, M.S.; et al. Combination Gemcitabine and WT1 Peptide Vaccination Improves Progression-Free Survival in Advanced Pancreatic Ductal Adenocarcinoma: A Phase II Randomized Study. Cancer Immunol. Res. 2018, 6, 320-331. [CrossRef] [PubMed]

123. Krug, L.M.; Dao, T.; Brown, A.B.; Maslak, P.; Travis, W.; Bekele, S.; Korontsvit, T.; Zakhaleva, V.; Wolchok, J.; Yuan, J.; et al. WT1 peptide vaccinations induce CD4 and CD8 T cell immune responses in patients with mesothelioma and non-small cell lung cancer. Cancer Immunol. Immunother. 2010, 59, 1467-1479. [CrossRef] [PubMed]

124. Erlich, R.L.; Jia, X.; Anderson, S.; Banks, E.; Gao, X.; Carrington, M.; Gupta, N.; DePristo, M.A.; Henn, M.R.; Lennon, N.J.; et al. Next-generation sequencing for HLA typing of class I loci. BMC Genom. 2011, 12, 42. [CrossRef] [PubMed] 
125. Robinson, J.; Halliwell, J.A.; Marsh, S.G.E. IMGT/HLA and the Immuno Polymorphism Database. Immunoinformatics 2014, 1184, 109-121. [CrossRef]

126. Yusim, K.; Korber, B.T.M.; Brander, C.; Barouch, D.; de Boer, R.; Haynes, B.F.; Koup, R.; Moore, J.P.; Walker, B.D.; Watkins, D.I. HIV molecular immunology database. Available online: https:/ /www.hiv.lanl.gov/content/immunology/compendium.html (accessed on 21 May 2014).

127. Vita, R.; Overton, J.A.; Greenbaum, J.A.; Ponomarenko, J.; Clark, J.D.; Cantrell, J.R.; Wheeler, D.K.; Gabbard, J.L.; Hix, D.; Sette, A.; et al. The immune epitope database (IEDB) 3.0. Nucleic Acids Res. 2015, 43, D405-D412. [CrossRef] [PubMed]

128. Vita, R.; Mahajan, S.; Overton, J.A.; Dhanda, S.K.; Martini, S.; Cantrell, J.R.; Wheeler, D.K.; Sette, A.; Peters, B. The Immune Epitope Database (IEDB): 2018 update. Nucleic Acids Res. 2019, 47, D339-D343. [CrossRef] [PubMed]

129. Hurley, C.K.; Kempenich, J.; Wadsworth, K.; Sauter, J.; Hofmann, J.A.; Schefzyk, D.; Schmidt, A.H.; Galarza, P.; Cardozo, M.B.R.; Dudkiewicz, M.; et al. Common, intermediate and well-documented HLA alleles in world populations: CIWD version 3.0.0. HLA 2020, 95, 516-531. [CrossRef]

130. Gragert, L.; Madbouly, A.; Freeman, J.; Maiers, M. Six-locus high resolution HLA haplotype frequencies derived from mixedresolution DNA typing for the entire US donor registry. Hum. Immunol. 2013, 74, 1313-1320. [CrossRef]

131. MedCalc Software Ltd. Comparison of Proportions Calculator. (Version 20.010). Available online: https://www.medcalc.org/ calc/comparison_of_proportions.php (accessed on 1 March 2021).

132. Campbell, I. Chi-squared and Fisher-Irwin tests of two-by-two tables with small sample recommendations. Stat. Med. 2007, 26, 3661-3675. [CrossRef]

133. Richardson, J.T. The analysis of $2 \times 2$ contingency tables-yet again. Stat. Med. 2011, 30, 890. [CrossRef] [PubMed]

134. Newcombe, R.; Altman, D. Proportions and Their Differences. In Statistics with Confidence: Confidence Intervals and Statistical Guidelines, 2nd ed.; Altman, D., Machin, D., Bryant, T., Gardner, M., Eds.; BMJ Books: London, UK, 2000; pp. 45-57.

135. Fawcett, T. An introduction to ROC analysis. Pattern Recognit. Lett. 2006, 27, 861-874. [CrossRef]

136. Šimundić, A.-M. Measures of Diagnostic Accuracy: Basic Definitions. EJIFCC 2009, 19, 203-211. [PubMed]

137. Somogyi, E.; Csiszovszki, Z.; Molnar, L.; Lorincz, O.; Toth, J.; Pattijn, S.; Schockaert, J.; Mazy, A.; Miklos, I.; Pantya, K.; et al. A Peptide Vaccine Candidate Tailored to Individuals' Genetics Mimics the Multi-Targeted T Cell Immunity of COVID-19 Convalescent Subjects. Front. Genet. 2021, 12, 684152. [CrossRef]

138. Toke, E.R.; Megyesi, M.; Molnar, L.; Tóth, J.; Lőrincz, O.; van der Burg, S.H.; Welters, M.; Melief, C.J.; Schönharting, W.; Urban, S.; et al. Prediction the clinical outcomes of cancer patients after peptide vaccination. J. Clin. Oncol. 2019, 37, e14295. [CrossRef]

139. Yuan, J.; Ku, G.Y.; Gallardo, H.F.; Orlandi, F.; Manukian, G.; Rasalan, T.S.; Xu, Y.; Li, H.; Vyas, S.; Mu, Z.; et al. Safety and immunogenicity of a human and mouse gp100 DNA vaccine in a phase I trial of patients with melanoma. Cancer Immun. 2009, 9,5 .

140. Bassani-Sternberg, M.; Bräunlein, E.; Klar, R.; Engleitner, T.; Sinitcyn, P.; Audehm, S.; Straub, M.; Weber, J.; Slotta-Huspenina, J.; Specht, K.; et al. Direct identification of clinically relevant neoepitopes presented on native human melanoma tissue by mass spectrometry. Nat. Commun. 2016, 7, 13404. [CrossRef]

141. Wells, D.K.; van Buuren, M.M.; Dang, K.K.; Hubbard-Lucey, V.M.; Sheehan, K.C.F.; Campbell, K.M.; Lamb, A.; Ward, J.P.; Sidney, J.; Blazquez, A.B.; et al. Key Parameters of Tumor Epitope Immunogenicity Revealed Through a Consortium Approach Improve Neoantigen Prediction. Cell 2020, 183, 818-834.e13. [CrossRef]

142. Kirner, A.; Mayer-Mokler, A.; Reinhardt, C. IMA901: A multi-peptide cancer vaccine for treatment of renal cell cancer. Hum. Vaccin. Immunother. 2014, 10, 3179-3189. [CrossRef]

143. Boegel, S.; Löwer, M.; Bukur, T.; Sorn, P.; Castle, J.C.; Sahin, U. HLA and proteasome expression body map. BMC Med. Genom. 2018, 11, 36. [CrossRef]

144. Zhang, Y.; Renkvist, N.; Sun, Z.; Schuler-Thurner, B.; Glaichenhaus, N.; Schuler, G.; Boon, T.; van der Bruggen, P.; Colau, D. A polyclonal anti-vaccine CD4 T cell response detected with HLA-DP4 multimers in a melanoma patient vaccinated with MAGE-3.DP4-peptide-pulsed dendritic cells. Eur. J. Immunol. 2005, 35, 1066-1075. [CrossRef] [PubMed]

145. Hicklin, D.J.; Marincola, F.M.; Ferrone, S. HLA class I antigen downregulation in human cancers: T-cell immunotherapy revives an old story. Mol. Med. Today 1999, 5, 178-186. [CrossRef]

146. Garrido, F.; Ruiz-Cabello, F.; Aptsiauri, N. Rejection versus escape: The tumor MHC dilemma. Cancer Immunol. Immunother. 2017, 66, 259-271. [CrossRef] [PubMed]

147. Chowell, D.; Morris, L.G.T.; Grigg, C.M.; Weber, J.K.; Samstein, R.M.; Makarov, V.; Kuo, F.; Kendall, S.M.; Requena, D.; Riaz, N.; et al. Patient HLA class I genotype influences cancer response to checkpoint blockade immunotherapy. Science 2018, 359, 582-587. [CrossRef] [PubMed]

148. Johnson, J.I.; Decker, S.; Zaharevitz, D.; Rubinstein, L.V.; Venditti, J.M.; Schepartz, S.; Kalyandrug, S.; Christian, M.; Arbuck, S.; Hollingshead, M.; et al. Relationships between drug activity in NCI preclinical in vitro and in vivo models and early clinical trials. Br. J. Cancer 2001, 84, 1424-1431. [CrossRef]

149. Hoos, A.; Parmiani, G.; Hege, K.; Sznol, M.; Loibner, H.; Eggermont, A.; Urba, W.; Blumenstein, B.; Sacks, N.; Keilholz, U.; et al. A clinical development paradigm for cancer vaccines and related biologics. J. Immunother. 2007, 30, 1-15. [CrossRef] [PubMed]

150. Bateman, A.C.; Turner, S.J.; Theaker, J.M.; Howell, W.M. HLA-DQB1*0303 and *0301 alleles influence susceptibility to and prognosis in cutaneous malignant melanoma in the British Caucasian population. Tissue Antigens 1998, 52, 67-73. [CrossRef] 
151. Chaudhuri, S.; Cariappa, A.; Tang, M.; Bell, D.; Haber, D.A.; Isselbacher, K.J.; Finkelstein, D.; Forcione, D.; Pillai, S. Genetic susceptibility to breast cancer: HLA DQB*03032 and HLA DRB1*11 may represent protective alleles. Proc. Natl. Acad. Sci. USA 2000, 97, 11451-11454. [CrossRef]

152. Aureli, A.; Canossi, A.; Del Beato, T.; Franceschilli, L.; Buonomo, O.; Papola, F.; De Sanctis, F.; Lanzilli, G.; Sileri, P.; Coppola, A.; et al. HLA-DRB1*13:01 allele in the genetic susceptibility to colorectal carcinoma. Int. J. Cancer 2015, 136, 2464-2468. [CrossRef]

153. Lesseur, C.; Diergaarde, B.; Olshan, A.F.; Wünsch-Filho, V.; Ness, A.R.; Liu, G.; Lacko, M.; Eluf-Neto, J.; Franceschi, S.; Lagiou, P.; et al. Genome-wide association analyses identify new susceptibility loci for oral cavity and pharyngeal cancer. Nat. Genet. 2016, 48, 1544-1550. [CrossRef]

154. Krul, E.J.; Schipper, R.F.; Schreuder, G.M.; Fleuren, G.J.; Kenter, G.G.; Melief, C.J. HLA and susceptibility to cervical neoplasia. Hum. Immunol. 1999, 60, 337-342. [CrossRef]

155. Kübler, K.; Arndt, P.F.; Wardelmann, E.; Krebs, D.; Kuhn, W.; van der Ven, K. HLA-class II haplotype associations with ovarian cancer. Int. J. Cancer 2006, 119, 2980-2985. [CrossRef] [PubMed]

156. Marty, R.; Kaabinejadian, S.; Rossell, D.; Slifker, M.J.; van de Haar, J.; Engin, H.B.; de Prisco, N.; Ideker, T.; Hildebrand, W.H.; Font-Burgada, J.; et al. MHC-I Genotype Restricts the Oncogenic Mutational Landscape. Cell 2017, 171, 1272-1283.e15. [CrossRef] [PubMed]

157. Shi, S.; Zhu, H.; Xia, X.; Liang, Z.; Ma, X.; Sun, B. Vaccine adjuvants: Understanding the structure and mechanism of adjuvanticity. Vaccine 2019, 37, 3167-3178. [CrossRef]

158. Petrovsky, N.; Aguilar, J.C. Vaccine adjuvants: Current state and future trends. Immunol. Cell Biol. 2004, 82, 488-496. [CrossRef]

159. Petrovsky, N. Comparative Safety of Vaccine Adjuvants: A Summary of Current Evidence and Future Needs. Drug Saf. 2015, 38, 1059-1074. [CrossRef] [PubMed]

160. Aucouturier, J.; Dupuis, L.; Deville, S.; Ascarateil, S.; Ganne, V. Montanide ISA 720 and 51: A new generation of water in oil emulsions as adjuvants for human vaccines. Expert Rev. Vaccines 2002, 1, 111-118. [CrossRef]

161. Janetzki, S.; Panageas, K.S.; Ben-Porat, L.; Boyer, J.; Britten, C.M.; Clay, T.M.; Kalos, M.; Maecker, H.T.; Romero, P.; Yuan, J.; et al. Results and harmonization guidelines from two large-scale international Elispot proficiency panels conducted by the Cancer Vaccine Consortium (CVC/SVI). Cancer Immunol. Immunother. 2008, 57, 303-315. [CrossRef]

162. Janetzki, S.; Cox, J.H.; Oden, N.; Ferrari, G. Standardization and Validation Issues of the ELISPOT Assay. In Handbook of ELISPOT: Methods and Protocols; Kalyuzhny, A.E., Ed.; Humana Press: Totowa, NJ, USA, 2005; pp. 51-86.

163. Lyerly, H.K. Quantitating cellular immune responses to cancer vaccines. Semin. Oncol. 2003, 30, 9-16. [CrossRef]

164. Van der Burg, S.H.; Arens, R.; Ossendorp, F.; van Hall, T.; Melief, C.J. Vaccines for established cancer: Overcoming the challenges posed by immune evasion. Nat. Rev. Cancer 2016, 16, 219-233. [CrossRef]

165. Galon, J.; Bruni, D. Approaches to treat immune hot, altered and cold tumours with combination immunotherapies. Nat. Rev. Drug Discov. 2019, 18, 197-218. [CrossRef] [PubMed]

166. Saxena, M.; van der Burg, S.H.; Melief, C.J.M.; Bhardwaj, N. Therapeutic cancer vaccines. Nat. Rev. Cancer 2021, $21,360-378$. [CrossRef] [PubMed]

167. Van der Burg, S.H. Correlates of immune and clinical activity of novel cancer vaccines. Semin. Immunol 2018, 39, 119-136. [CrossRef] [PubMed] 